\title{
Avrupa Birliği Ülkelerinin İhracatındaki Yurtiçi Katma Değerin Belirleyicileri
}

\author{
Huriye ALKIN KASAPLAR*
}

ÖZ

Bu çalışmanın amacı, Dünya Girdi Çıktı Veri Tabanı (WIOD) kullanılarak 2000-2014 yıllarını kapsayan dönemde 28 ülkeden oluşan Avrupa Birliği bölgesinin küresel değer zincirine katılımının araştırılmasıdır. Küresel değer zinciri ölçüm yöntemi olarak Koopman, Wang and Wei (2014) tarafindan geliştirilen ayrıştırma metodu kullanılmıştır. Günümüzde üretimin farklı aşamalarını farklı ülkelerin gerçekleştirmesi ve ara girdilerin uluslararası sınırlardan çok kez geçmesi sebebi ile geleneksel dış ticaret istatistikleri farklı ülkeler tarafından elde edilen katma değeri içermektedir. Dolayısıyla dış ticaret istatistikleri çift sayım problemi ile karşı karşıyadır. Geliştirilen ayrıştırma metodu ile brüt ihracat, katma değer ve çift sayım bileşenlerinden oluşan birçok bileşene ayrılarak bu sorunun önüne geçilmektedir. Ülkelerin ihracatındaki yurtiçi katma değer ve yabancı katma değerin hesaplandığı analizin ilk kısmında 2000-2014 yılları arasında ülkelerin ihracatındaki yurtiçi katma değerin azaldığı ve yabancı katma değerin arttığı sonucuna ulaşılmıştır. Analizin ikinci kısmında verimlilik, araştırma ve geliştirme yatırımları, sermaye birikimi, yabancı katma değer, bilgiişlem donanım yatırımları ve iletişim yatırımlarının ihracattaki yurt içi katma değer üzerindeki etkisi analiz edilmektedir. Ülke bazlı olarak yapılan çalışmanın ampirik sonuçları araştırma ve geliştirme yatırımları, sermaye stoku ve yabancı katma değerin yurtiçi katma değeri pozitif etkilediğini göstermektedir.

Anahtar Kelimeler: Küresel Değer Zinciri, İhracatta Katma Değer, Dikey Uzmanlaşma, WIOD

JEL Sinıflandırması: F10, F12, F13

\section{The Determinants of Domestic Value Added in Exports of European Union Countries}

\begin{abstract}
The aim of this study is to examine the participation of European countries in global value chains between 2000 and 2014 using World Input Output Database (WIOD). Gross exports accounting method of Koopman, Wang and Wei (2014) is used for measurement of global value chains. The international trade statistics contain the value added which is acquired by different countries because of carrying out different stages of production by different countries and crossing borders more than once of intermediate inputs. Therefore, the international trade statistics have double counting problem. This problem is solved by decomposing of gross exports to various value added and double counted components with the method of gross exports accounting. In the first part of analysis, the domestic value added and foreign value added of exports of countries are calculated. The conclusion of the first part is that domestic value added of exports of countries decrease and foreign value added of exports increase between 2000 and 2014. In the second part of analysis, the effect of productivity, research and development investments, capital accumulation, foreign value added, computing equipment investment and communication equipment on the domestic value added of export is analyzed. The empirical conclusions of the study which is country-level demonstrate that research and development investment, capital accumulation and foreign value added effect the domestic value added positively.
\end{abstract}

Keywords: Global Value Chains, Domestic Value Added of Export, Vertical Specialization, WIOD

JEL Classification: F10, F12, F13

Geliş Tarihi / Received: 11.04.2019 Kabul Tarihi / Accepted: 12.07.2019

\footnotetext{
* Arş. Gör., Akdeniz Üniversitesi, İIBF, İktisat Bölümü, huriyealkin@ @akdeniz.edu.tr, ORCID: 0000-0002-6328-3381.
} 


\section{GİRIŞ}

Değer zinciri, firma ve işgücünün ürün/mal ve hizmet üretim aşamalarının tümünü kapsayan faaliyetleri içermektedir. Bu faaliyetler dizayn, üretim, pazarlama, dağıtım ve nihai tüketiciye destek olarak tanımlanabilir. Son otuz yıl içerisinde gelişmekte olan ülke ve yükselen piyasa ekonomilerinin ithal ikameci modelden ihracata dayalı sanayileşme modeline geçmesiyle küresel değerin yükselişi çarpıcı biçimde dünya mal ve hizmet üretiminin yapısını değiştirmiştir. Dünya Ticaret Örgütü Raporu (2008, s.20) taşıma, bilgi ve iletişim maliyetlerindeki azalmalar, artan teknolojik ilerleme ve politik ve ekonomik engellerdeki azalmaların üretimdeki parçalanmayı hızlandırdığına işaret etmektedir. Maliyetlerdeki azalma, teknolojik ilerleme ve engellerdeki azalma dünyanın farklı noktalarındaki fabrikalarda parça ve bileşenlerin birleştirilerek nihai mal ve hizmet elde edilmesini mümkün kılmıştır. Ayrıca, ticaret anlaşmaları da arz zincirindeki potansiyel üyeler arasındaki üretim ağlarının yaratılmasını ve güçlenmesini teşvik etmektedir. Bu sebeple küresel değer zinciri (KDZ) küreselleşmenin en önemli ve göze çarpan özelliğini teşkil etmektedir.

Küresel değer zincirinde meydana gelen artış ile değer zinciri, nihai üründen ziyade ara mal ile ilişkilendirilir olmuştur. Birleşmiş Milletler Ticaret ve Kalkınma Konferansı (UNCTAD) 2013 Dünya Yatırım Raporu, küresel ticaretin \% 60'ının ara mal ve hizmetten oluştuğunu göstermektedir. $\mathrm{Bu}$ sebeple $\mathrm{KDZ}$, karşılaştırmalı üstünlükleri sektörlerden ziyade üretim aşamalarına kaydıran bir paradigmal değişim yaratmıştır. Dış ticaretten fayda elde edilmesi endüstriler arasında girdi temininin sağlanması ve uluslararası firmalarla ilişkilerin kurulmasına bağlıdır. Dolayısıyla, KDZ analizi ülkelerin birbirine bağımlılığının arttı̆̆ı bir dünyada ülkelerin refahının arttığının anlaşılması yanında değerin uluslararası çapta yaratıldığının ve dağıtıldığının anlaşılmasını da gerektirir. KDZ diş ticaret, verimlilik ve işgücü piyasa gelişimi yanında eşitsizlik, yoksulluk ve doğayı da etkilemektedir (Amador ve Cabral, 2016, s.278-79). Sonuç olarak, KDZ'deki büyüme uluslararası ticaret politikalarının, dış rekabetçiliğinin ve ülkeler arasındaki ekonomik bağımlılığın yapısını değiştirmiştir.

Brüt olarak açıklanan ve hem ara girdi hem de nihai çıktıyı içeren tüm resmi dış ticaret istatistiklerinde uluslararası sınırlardan birden fazla geçen ara malın değeri çift sayılmaktadır. Günümüzde üretimin farklı aşamalarını farklı ülkelerin gerçekleştirilmesi ve ara girdilerin uluslararası sınırlardan çok kez geçmesi sebebi ile geleneksel dış ticaret istatistikleri güvenilirliğini yitirmektedir. Koopman, Wang ve Wei (2014), küresel değer zincirini ölçmek için geliştirilen diğer ölçüm yöntemlerinden ${ }^{1}$ farklı olarak diş ticaret istatistiklerindeki bu elverişsizliğin önüne geçmek için brüt ihracatın katma değer ve çift sayım bileşenlerinden oluştuğu bir ayrıştırma yöntemi geliştirmektedir. Ülke düzeyinde ihracat için geliştirilen ve dokuz ayrı alt bileşenden oluşan bu ayrıştırma metodu, dört ayrı büyük başlık altında toplanmaktadır. İlki, ihracattaki yurtiçi katma değerdir. Bu katma değer yurtdışında tüketilmektedir. İkincisi, önce ihraç edilen ardından ülkeye geri dönen yurtiçi katma değerdir. Bu katma değer, ihracattaki katma değer içerisinde yer almayıp ihracatçı ülkenin gelirinin bir kısmını oluşturmaktadır. Üçüncüsü, ihracat yapan ülkenin kullandığı yabancı katma değerdir. Dördüncü başlık ise çift sayım bileşeni olup bu bileşen ile uluslararası sınırlarda çok kez sayılan ara mal ticareti ifade edilmek istenmektedir.

$\mathrm{Bu}$ çalışmanın amacı, Avrupa Birliği ülkelerinin küresel değer zincirine katılımının araştırılmasıdır. Çalışmanın tanımlayıcı analiz kısmında Koopman vd. (2014) tarafından geliştirilen KWW (2014) ayrıştırma metodu kullanılarak 2000-2014 yıllarını kapsayan dönemde 28 Avrupa Birliği ülkesinin brüt ihracatındaki yurtiçi katma değer ve yabanc1 katma değer bileşenleri hesaplanmaktadır. Tanımlayıcı analiz ile 2000 yılına kıyasla 2014 yılında ülkelerin

\footnotetext{
${ }^{1}$ Feenstra ve Hanson (1996); Feenstra ve Hanson (1999); Hummels, Ishii ve Yi (2001); Daudin, Rifflart ve Schweisguth (2011); Johnson ve Noguera (2012)
} 
ihracatlarındaki yurtiçi katma değerin azaldığı ve yabancı katma değerin arttığı sonucuna ulaşılmaktadır. Analizin ikinci kısmında yurtiçi katma değerin belirleyicileri incelenmiştir. Verimlilik, araştırma ve geliştirme yatırımı, sermaye birikimi, yabancı katma değer, işgücü verimliliği, bilgi-işlem donanım yatırımı ve iletişim yatırımı değişkenlerinin yurtiçi katma değer üzerindeki etkisinin incelendiği ampirik analiz sonuçları, yabancı katma değer, sermaye stoku ve araştırma ve geliştirme yatırımlarının yurtiçi katma değeri arttırdığını göstermektedir

Çalışmanın ikinci bölümünde küresel değer zinciri ölçüm yöntemleri yer almaktadır. İkinci bölümün sonunda literatüre yer verilmektedir. Üçüncü bölümde analiz ve son bölümde de sonuç yer almaktadır.

\section{KÜRESEL DEĞER ZINCİRİ ÖLÇME YÖNTEMLERI}

Küresel değer zincirinin ölçümü için farklı birçok ölçüm yöntemi geliştirilmiştir. İlki, üretim ya da toplam girdilerde ithal edilen girdi payını veren yurtiçi üretimdeki yabancı içeriktir. Bu hesaplama yöntemi ilk olarak Feenstra ve Hanson (1996) tarafından kullanılmıştır. Feenstra ve Hanson (1999) dış kaynak kullanımını geniş ve dar anlamda olmak üzere iki ayrı biçimde hesaplamıştır. Geniş olanı, her imalat endüstrisinin diğer endüstrilerden satın aldığg ara malların değerini ifade etmektedir. Dış kaynak kullanımının dar anlamda olanı ise üretimin yapıldığ 1 sektörden girdi temini ile ilintilidir. Geliştirilen ikinci ölçüm yöntemi dikey uzmanlaşmadır ve Hummels vd. (2001) tarafından oluşturulmuştur. Dikey uzmanlaşma, ihracat için ithal girdiye ihtiyaç duyularak ithalatın yapıldığ 1 ve malların uluslararası sınırlarda en az iki defa değişiminin yapıldığı durumlarda geçerli olmaktadır. Hummels vd. (2001), ülkelerin ihraç mallarındaki ithal girdi oranını diğer bir ifade ile dikey uzmanlaşma oranını, OECD veri tabanını kullanarak hesaplamaktadır. Hummels, Ishii ve Yi (HIY), çalışmalarında matematiksel denklemini oluşturmadıkları başka bir ölçüm yöntemi daha geliştirmektedirler. Bu ölçüm yönteminde ihracat yapılan ülke dışında yer alan üçüncü ülkelere dolaylı olarak gönderilen ara mal ihracatının değeri hesaplanmaktadır. Üçüncü ölçüm yöntemi Daudin, Rifflart ve Schweisguth (2011) tarafindan geliştirilmiştir. Bu ölçüm yönteminde herhangi bir ülkenin, diğer ülkeler tarafindan nihai mal üretiminde ithal girdi olarak kullanılan ve o ülkeye geri dönen ihracatının değeri hesaplanmaktadır. İhracattaki katma değerin ölçüldüğü dördüncü ölçüm yöntemi ise Johnson ve Noguera (2012) tarafından geliştirilmiş̧tir. Johnson ve Noguera (2012) ihracattaki katma değeri, nihai mal ihracatından elde edilen geliri gayrisafi ihracata bölerek elde etmektedir. Johnson ve Noguera (2012), GTAP ve WIOD veri tabanını kullanarak uluslararası ticaretteki yerli ve yabancı katma değeri ayrıştırmak amacıyla ikili ticaret akımlarına odaklanarak ihracattaki katma değerin brüt ihracata oranını hesaplamışlardır. Koopman vd. (2014) tarafından geliştirilen beşinci ölçüm yönteminde, dış ticaret istatistiklerindeki çoklu sayımın önüne geçmek için brüt ihracattaki yabancı katma değer ve yurtiçi katma değer çift sayım bileşenlerinden ayrıştırılarak net değer olarak hesaplanmaktadır.

\subsection{KWW (2014) Ayrıştırma Yöntemi}

Dış ticarette katma değer ya da dikey uzmanlaşma ile ilgili ayrıştırma metotlarının kökenlerinin Leontief (1936)'e dayanması sebebi ile Leontief ayrıştırma metodunun aşamalarının irdelenmesi önem arz etmektedir. Koopman vd. (2014), iki ülkeden oluşan bir dünyada ülkelerin $\mathrm{N}$ farklı ürün ürettiğinin varsayıldığı bir örnekle Leontief ayrıştırma metodunu açıklamaktadır. Her sektörde ürün ya tüketilmekte ya da ara girdi olarak kullanılmaktadır. Ayrıca her iki ülke de ara ve nihai mal ve hizmet ihraç etmektedir. S ülkesi tarafından üretilen ürün yurtdışında ya da ülkede ara girdi ya da nihai ürün olarak tüketilmektedir.

$X_{s}=A_{s s} X_{s}+Y_{s s}+A_{s r} X_{r}+Y_{s r} \quad r, s=1,2$ 
Üstte (1) numaralı denklemde yer alan $X_{S}$, s ülkesinin $\mathrm{Nx1}$ boyutlu brüt çıktı vektörünü, $Y_{s r}$, s ülkesi tarafindan üretilip $\mathrm{r}$ ülkesi tarafindan nihai talep olarak tüketilen $\mathrm{Nx} 1$ boyutlu nihai talep vektörünü ve $A_{s r}$, s ülkesinde üretilen mal ve hizmetin $\mathrm{r}$ ülkesi tarafindan ara girdi olarak kullanılan kısmını göstermekte olup $\mathrm{NxN}$ boyutlu girdi çıktı katsayı matrisi olarak ifade edilmektedir. İki ülkenin yer aldığ 1 üretim ve ticaret sistemi (2) numaralı denklemden itibaren gösterilmektedir.

$\left[\begin{array}{l}X_{s} \\ X_{r}\end{array}\right]=\left[\begin{array}{ll}A_{s s} & A_{s r} \\ A_{r s} & A_{r r}\end{array}\right]\left[\begin{array}{l}X_{s} \\ X_{r}\end{array}\right]+\left[\begin{array}{l}Y_{s s}+Y_{s r} \\ Y_{r s}+Y_{r r}\end{array}\right]$

Gerekli düzenlemenin ardından Leontief ters matris matrisi oluşturulmaktadır.

$\left[\begin{array}{l}X_{s} \\ X_{r}\end{array}\right]=\left[\begin{array}{cc}I-A_{s s} & -A_{s r} \\ -A_{r s} & I-A_{r r}\end{array}\right]^{-1}\left[\begin{array}{c}Y_{s s}+Y_{s r} \\ Y_{r s}+Y_{r r}\end{array}\right]=\left[\begin{array}{ll}B_{s s} & B_{s r} \\ B_{r s} & B_{r r}\end{array}\right]\left[\begin{array}{l}Y_{s} \\ Y_{r}\end{array}\right]$

$\mathrm{NxN}$ blok matrisinden oluşan $B_{s r}$, Leontief ters matrisi olarak ifade edilmektedir. Leontief ters matris toplam gereklilik matrisi olarak tanımlanmakta olup, $r$ ülkesinin 1 birimlik nihai mal talep artışını karşılamak için $\mathrm{s}$ ülkesinin yapması gereken üretim miktarını göstermektedir. Denklemde yer alan $Y_{S}$, s ülkesinin nihai ürününün küresel talebini $\left(Y_{S S}, \mathrm{~s}\right.$ ülkesinin yurtiçi nihai satışı ve $Y_{s r}$, nihai ürün ihracatını tanımlamakta) ifade etmektedir. 1 dolarlık ihracat yapmak için gerçekleştirilen üretimden elde edilen katma değer $\mathrm{V}$ olup elde edilen katma değer direkt katma değer olarak ifade edilmektedir. İhracat yapmak için ara girdiler de kullanılmaktadır ve üretilen bu ara girdi dolaylı katma değer yaratmaktadır. Ara mal kullanıldıkça diğer ara girdilerinin de üretilmesiyle bu döngü devam etmektedir. 1 dolarlık ihracatın yaratmış olduğu katma değer, direkt ve bütün dolaylı katma değerlerin toplamına eşittir.

Toplam Katma Değer $=V+V A+V A A+V A A A \ldots=V\left(I+A+A^{2}+A^{3}+\cdots\right)=V(I-\mathrm{A})^{-1}=V B$

(4) numaralı denklem G tane ülke olacak şekilde düzenlenerek (5) numaralı denklemde yer alan toplam katma değer denklemine ulaşılmaktadır.

$\left[\begin{array}{cccc}V_{s} B_{s s} & V_{s} B_{s r} & \cdots & V_{s} B_{S G} \\ V_{r} B_{r s} & V_{r} B_{r r} & \cdots & V_{r} B_{r G} \\ \vdots & \vdots & \ddots & \vdots \\ V_{G} B_{G s} & V_{G} B_{G r} & \cdots & V_{G} B_{G G}\end{array}\right]$

İhracatçı ülke olan $S$ ülkesinin diğer ülkelere toplam katma değer ihracatı (6) numaralı denklemde gösterilmektedir.

$V T_{s^{*}}=\sum_{r \neq s}^{G} V X_{s r}=V_{s} \sum_{r \neq s}^{G} \sum_{G=1}^{G} B_{s G} Y_{G r}$

(6) numaralı denklem katma değerin nerede ve nasıl kullanıldığına bağlı olarak üç bileşene ayrıştırılmaktadır.

$V T_{s^{*}}=V_{s} \sum_{r \neq s}^{G} B_{s s} Y_{s r}+V_{s} \sum_{r \neq s}^{G} B_{s r} Y_{r r}+V_{s} \sum_{r \neq s}^{G} \sum_{t \neq s, r}^{G} B_{s r} Y_{s t}$

(7) numaralı denklemde, katma değer ihracatı ülkelerin nihai talepleri bağlamında ayrıştırılmaktadır. İlk bileşen, ihracatçı ülkenin nihai mal ihracatındaki katma değeri; ikinci bileşen, ihracatçı ülkenin direkt ithalatçı ülkeye yaptığı ara mal ihracatındaki - ardından ithalatçı ülke tarafından üçüncü ülkelerin nihai mal üretimlerini yapması amacıyla ihraç edilmekte - katma değeri; üçüncü bileşen, ihracatçı ülkenin direkt ithalatçı ülkeye yaptığı ara mal ihracatındaki ardından ithalatçı ülke tarafından üçüncü ülkelerin nihai mal tüketimleri için ihracat yapılmakta katma değeri göstermektedir.

İhracatçı ülkenin diğer ülkelere brüt ihracatı, (8) numaralı denklemde gösterilmektedir.

$E_{s^{*}}=\sum_{r \neq s}^{G} E_{s r}=\sum_{r \neq s}^{G} A_{s r} X_{r}+Y_{s r}$

Brüt ihracat, birçok bileşene ayrıştırılarak (9) numaralı denklem elde edilmektedir. 


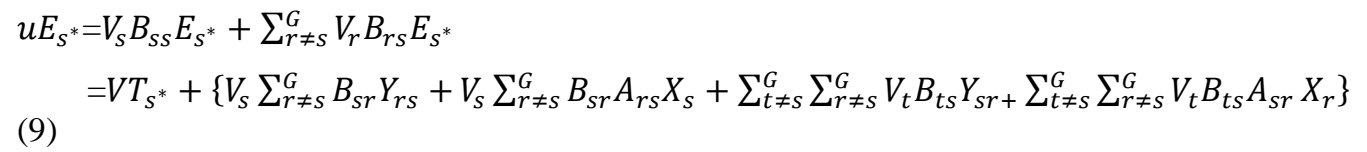

Her ülkenin brüt çıktı özdeşliğine bağlı olarak - $X_{S}=A_{s S} X_{S}+Y_{S S}+E_{S^{*}}$; ; ülkelerin brüt çıktıları, (10) numaralı denklemde yer aldığı gibi yazılmaktadır.

$$
\begin{aligned}
& X_{s}=\left(I-A_{s S}\right)^{-1} Y_{S S}+\left(I-A_{s S}\right)^{-1} E_{S^{*}} \\
& X_{r}=\left(I-A_{r r}\right)^{-1} Y_{r r}+\left(I-A_{r r}\right)^{-1} E_{r^{*}}
\end{aligned}
$$

(9) numaralı denklemde yer alan $X_{S}$ ve $X_{r}$, (10) numaralı denklemde olduğu gibi yazılarak (7) numaralı denklemde yerine konulduğunda brüt ihracat ayrıştırma metoduna ulaşılmaktadır.

$E_{s^{*}}=\left\{V_{s} \sum_{r \neq s}^{G} B_{s S} Y_{s r}+V_{s} \sum_{r \neq s}^{G} B_{s r} Y_{r r}+V_{s} \sum_{r \neq s}^{G} \sum_{t \neq s, r}^{G} B_{s r} Y_{r t}\right\}+\left\{V_{s} \sum_{r \neq s}^{G} B_{s r} Y_{r s}+V_{s} \sum_{r \neq s}^{G} B_{s r} A_{r s}(\mathrm{I}-\right.$ $\left.\left.A_{s s}\right)^{-1} Y_{s s}\right\}+V_{s} \sum_{r \neq s}^{G} B_{s r} A_{r s}\left(\mathrm{I}-A_{s s}\right)^{-1} E_{s^{*}}+\left\{\sum_{t \neq s}^{G} \sum_{r \neq s}^{G} V_{t} B_{t s} Y_{s r}+\sum_{t \neq s}^{G} \sum_{r \neq s}^{G} V_{t} B_{t s} A_{s r}\left(\mathrm{I}-A_{r r}\right)^{-1} Y_{r r}\right\}$

$+\sum_{t \neq s}^{G} V_{t} B_{t s} A_{s r} \sum_{r \neq s}^{G}\left(\mathrm{I}-A_{r r}\right)^{-1} E_{r^{*}}$

(11) numaralı denklemde birinci köşe parantezinin içinde yer alan üç bileşen, ihracattaki katma değeri göstermektedir. İkinci köşe parantezinin içinde yer alan iki bileşen, ülkenin ihraç edilip ülkeye geri dönerek ülkede tüketilen ara mal ve nihai mal ithalatındaki katma değeri ifade etmektedir. Üçüncü köşeli parantezin içinde yer alan iki bileşen, ülkenin brüt ihracatındaki yabancı katma değeri ifade etmekte iken altıncı ve dokuzuncu bileşenler, ara mal ticaretindeki çift sayımı göstermektedir.

1 numaralı şekilde yer alan $(1)+(2)+(3)+(4)+(5)+(6)$ numaralı bileşenler, ülkenin ihracatındaki yurtiçi içeriği; (7)+(8)+(9) numaralı bileşenler, ihracattaki yabancı içeriği (dikey uzmanlaşmayı) göstermektedir. (4) numaralı denklemden başlayarak (9) numarayı da içine alan bileşenler, ulusal sinırlarda en az iki kez işlem görmektedir.

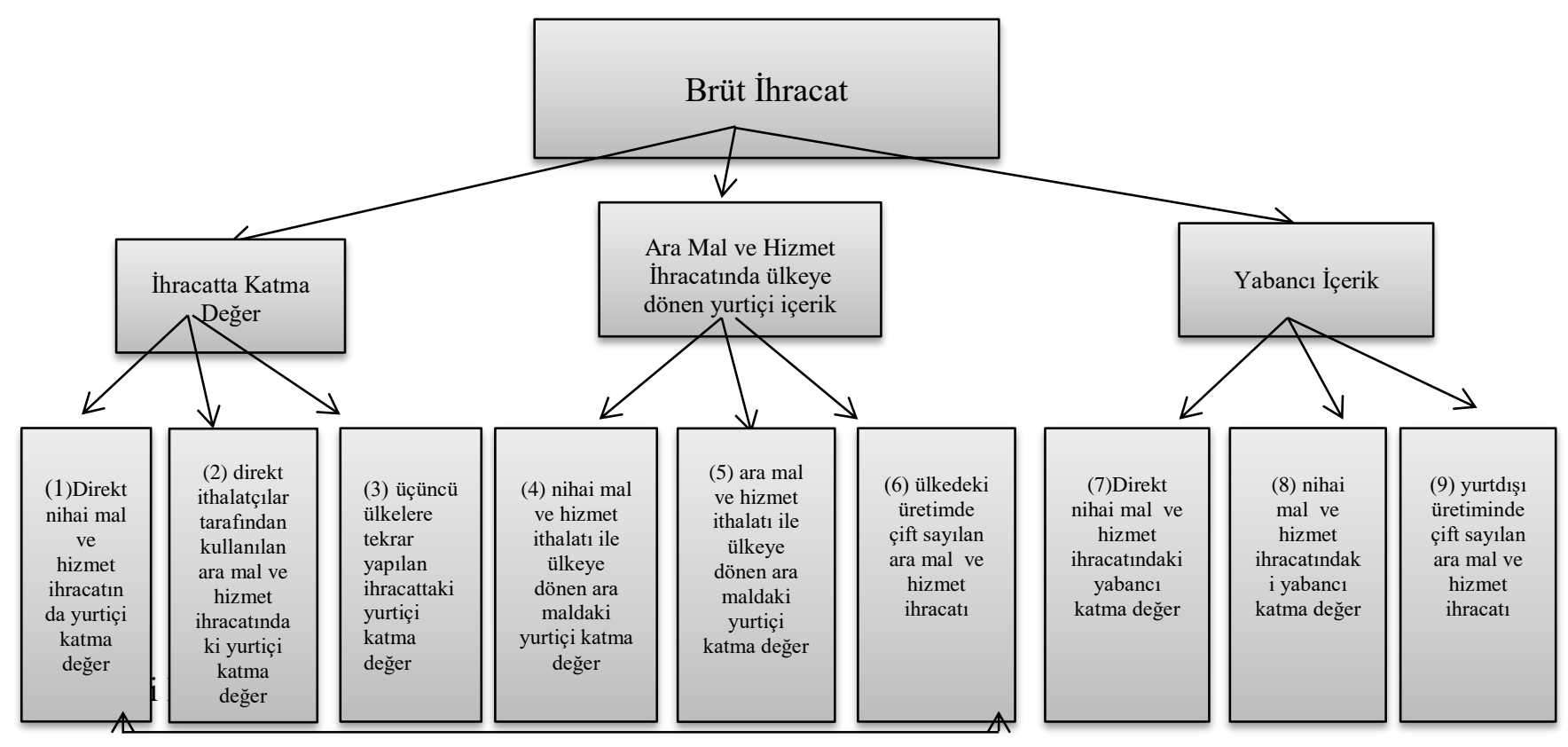

Şekil 1. KWW (2014) Brüt İhracat Ayrıştırma Yöntemi

Kaynak: Koopman vd. (2014). 
Aşağıda yer alan tabloda, KWW (2014) ayrıştırma metodunda yer alan bileşenlerin tanımlarına yer verilmektedir.

Tablo 1: KWW (2014) Brüt İhracat Bileşenlerinin Tanımları

KWW brüt ihracat

Tanım

ayrıştırma metodu

\begin{tabular}{|c|c|}
\hline Bileşen 1 & Nihai mal ve hizmet ihracatındaki yurtiçi katma değer \\
\hline Bileşen 2 & $\begin{array}{l}\text { Diğer ülkelerin yurtiçi nihai mal ve hizmet kullanımı için yap } \\
\text { ihracatındaki yurtiçi katma değer }\end{array}$ \\
\hline Bileşen 3 & $\begin{array}{l}\text { Diğer ülkelerin nihai mal ve hizmet ihracatları için kullanmal } \\
\text { yapılan ara malın ihracatındaki yurtiçi katma değer }\end{array}$ \\
\hline Bileşen 4 & $\begin{array}{l}\text { Diğer ülkelerden yapılan nihai mal ve hizmet ithalatı içind } \\
\text { yurtiçi katma değer }\end{array}$ \\
\hline Bileşen 5 & Ara mal ve hizmet ithalatında geri dönen yurtiçi katma değer \\
\hline Bileşen 6 & Brüt ihracatta çift sayılan yurtiçi katma değer \\
\hline Bileşen 7 & Nihai mal ve hizmet ihracatındaki yabancı katma değer \\
\hline Bileşen 8 & Ara ma ve hizmet 1 ihracatındaki yabancı katma değer \\
\hline Bileșen 9 & Ülkenin ihracatında çift sayılan yabancı katma değer \\
\hline
\end{tabular}

Kaynak: Koopman vd. (2014)

\subsection{Literatür}

Avrupa Birliği bölgesinin küresel değer zincirindeki konumunu farklı ölçüm yöntemleri, farklı veri kaynakları ile farklı dönemlerde analiz eden çalışmalar mevcuttur. Bu çalışmaların büyük çoğunluğunda Avrupa Birliği'nde yer alan belli başlı ülkelerin ihracattaki yurtiçi katma değeri ve yabancı katma değeri hesaplanarak tanımlayıcı analiz yapılmıştır. KWW (2014) yöntemi kullanılarak Avrupa Birliği ülkelerinin hepsinin brüt ihracatlarının ayrı kalemlere ayrıştırılması ile ülkelerin küresel değer zincirine daha detaylı bakıldığı çalışma (araştırmamız dahilinde ve bildiğimiz kadarıyla) rastlanmamıştır. Literatürde küresel değer zinciri ile yapılan çalışmalar daha çok tanımlayıcı analiz niteliğinde olup ampirik çalışmalar görece daha azdır. Yapılan bu ampirik çalışmaların birçoğunda küresel değer zincirinin belirleyicileri analiz edilmekte bir kısmında da çekim modeli ile analiz gerçekleştirilmektedir.

Avrupa Birliği'nin küresel değer zincirindeki konumunun analiz edildiği ya da Avrupa Birliği ülkeleri ile karşılaştırma yapılan çalışmalara örnek olarak Timmer vd. (2013), Koopman vd. (2014), Cappariello vd. (2015), Benkovskis ve Wörz (2016), Solaz (2018), Donofrio vd. (2018) ve Yu ve Zhechong (2018) çalışmaları örnek verilebilir. Timmer vd. (2013), çalışmasında küresel değer zinciri geliri adındaki kendi geliştirdikleri gösterge değişkeni kullanarak, Avrupa Birliği Bölgesi için 1995-2008 yıllarını kapsayan analizlerini gerçekleşmektedirler. Ampirik çalışmanın sonucu, bazı Avrupa Birliği ülkelerinin imalat sektörü ihracat büyümesi ve imalat sektöründe gelir ve istihdam yaratma arasında korelasyonun olmadığına işaret etmektedir. Ulaşılan sonuç, gelişmekte olan ülkelerin ihracatlarının ağırlıklı olarak ithalata bağlı olduğu ile açıklanmaktadır. 
Ulaş1lan bir başka sonuç, düşük nitelikli işgücünden yükssek nitelikli işgücüne doğru dönüşümün gerçekleştiğidir. Koopman vd. (2014), ayrıştırma modelini geliştirdikleri çalışmalarında ülkeleri gelişmiş ülkeler, Asya Ülkeleri, Yükselen Asya Ülkeleri ve diğer gelişmekte olan ülkeler olarak gruplayarak bu ülkelerin 2004 yılına ait ihracatlarını dokuz ayrı bileşene ayırmaktadırlar. Çalışmanın sonuçları, Batı Avrupa ülkelerinin ihracattaki yurtiçi katma değerin 78,2 iken Avrupa Birliği'ne yeni katılan ülkelerde bu oranın 68 olduğuna işaret etmektedir.

Cappariello vd. (2015), çalışmalarında KWW (2014) ayrıştırma yöntemini kullanarak küresel değer zincirinin Avrupa Birliği bölgesinin ekonomik entegrasyonu üzerindeki rolünü analiz etmektedirler. Çalışmada karşılaştırma yapmak amacıyla Japonya, Çin ve Amerika Birleşik Devletleri de analize dâhil edilmektedir. Analiz sonucunda Avrupa Birliği bölgesinde 2000-2011 yılarını kapsayan 11 yıllık süreçte yabancı katma değerin artış trendine sahip olduğu sonucuna ulaşılmaktadır. 2011 krizi ile birlikte Avrupa Birliği bölgesinin ithal girdi kullanımında Çin'in payı azalırken Japonya ve diğer Asya ülkelerinin payında 1lımlı bir artış olduğu saptanmaktadır. Küresel krizin ardından küresel değer zincirinde Çin'in, Avrupa Birliği bölgesinden daha güçlü katılım sağladığına işaret edilmektedir. Ayrıca, her ne kadar Çin'in ihracatta üretime dönük pozisyon alsa da Avrupa Birliği bölgesinin Japonya ve Çin'e nazaran küresel değer zincirinde daha çok üretime dönük olduğu sonucuna ulaşılmaktadır. Benkovskis ve Wörz (2016), çalışmalarında geleneksel brüt ihracattan ihracat piyasa paylarında katma değere geçişin piyasa paylarını değiştirmediği sonucuna ulaşmaktadırlar (Avrupa Birliği'ne yeni katılan ülkeler, Avrupa Birliği’ne üye eski ülkeler yardımı ile piyasa payı edinmektedirler). Analiz sonucunda uluslararası üretimde parçalanma ile küresel üretim aşamalarının, Avrupa Birliği yeni üyelerine doğru kaydığ sonucuna ulaşılmaktadır. Çalışmanın sonuçları ayrıca, küresel piyasa payını açıklamada fiyat faktörünün önemli olduğunu göstermektedir. Solaz (2018), KWW (2014) yöntemini baz aldığ1 çalışmasında İspanya'nın küresel değer zincirindeki ekonomik bütünleşmesini ekonominin bütünü için ve sektör bazında analiz etmektedir. Küresel değer zincirinde geriye doğru katılıma vekil olarak ihracatta katma değer ve dış kaynak kullanımı kullanılmaktadır. Ampirik sonuçlar, İspanya'nın dikey uzmanlaşmaya aktif olarak dâhil olduğunu ve ithal girdi kullanımının, 1995'den 2011'e kadar \% 9 oranından daha çok arttığını göstermektedir. Analiz sonucunda, imalat sanayiinde elde edilen katma değerin önemli bir kısmının, hizmet sektörü kaynaklı olduğu tespit edilmiştir. Donofrio vd. (2018), KWW (2014) ayrıştırma yöntemini kullanarak Avrupa Birliği bölgesi için yaptığı ve 1995-2011 yıllarını kapsayan çalışmalarında, analizi ihracatçı ve ithalatçı ülkenin geliri, iki ülke arasındaki uzaklık, kullanılan dil gibi değişkenleri kullanarak çekim modeli ile gerçekleştirmektedir. Analiz sonucunda bütün değişkenlerin, yurtiçi katma değeri pozitif etkilediği sonucuna ulaşılmaktadır. Yu ve Zhechong (2018), çalışmalarında WIOD veri tabanını kullanarak Çin'in küresel değer zincirine nasıl ve ne şekilde dâhil olduğunu 1995-2011 y1lları için analiz etmişlerdir. Analiz sonuçları, Çin'in ihracattaki katma değerinin Amerika Birleşik Devletleri, Japonya, Kanada ve İngiltere'den daha düşük olduğunu göstermektedir. Çalışmanın ikinci kısmında, ihracatta yurtiçi katma değerin belirleyicileri analiz edilmiştir. Ampirik çalışmanın sonucunda verimlilik, sermaye birikimi, teknoloji ya da bilgi kaynaklı araştırma ve geliştirme yatırımları ve dikey uzmanlaşmanın yurtiçi katma değeri arttırdığı sonucu elde edilmiştir.

Literatürde yapılan çalışmalardan çıkarılacak sonuç, ihracatta yurtiçi katma değerin 2000'li yılların başlarından itibaren azaldığı ve yabancı katma değerin artığı yönündedir. Bu bağlamda üretimde parçalanmanın ya da dikey uzmanlaşmanın arttığı açıktır.

\section{ANALIZ}

Analiz iki ayrı bölümden oluşmaktadır. İlk bölüm, toplam 28 ülkeden oluşan Avrupa Birliği ülkelerinin küresel değer zincirindeki konumunun saptandığ 1 tanımlayıcı analizdir. Tanımlayıcı analizde, 28 Avrupa Birliği ülkesinden diğer ülkelere yapılan ihracat brüt ihracat ayrıştırma 
metodu kullanılarak 9 ayrı bileşene ayrılmaktadır. Brüt ihracat, bileşenlere ayrıştırılarak brüt ihracatın ne kadar yurtiçi katma değer ve yabancı katma değer içerdiği daha net görülebilecektir. İkinci bölüm, 7 Avrupa Birliği ülkesinin verilerinin tam olmaması sebebi ile 21 Avrupa Birliği ülkesi için yapılan ampirik analizdir. İhracat alt bileşenlerinde yer alan $(1)+(2)+(3)+(4)+(5)$ numaralı bileşenler hesaplanarak, ülkelerin ihracatındaki yurtiçi katma değer elde edildikten sonra ülkelerin ihracatındaki yurtiçi katma değerin belirleyicileri incelenmiştir.

\subsection{Tanımlayıcı Analiz}

Geliştirilen ayrıştırma metodunda yer alan 1, 2, 3, 4,5 numaralı bileşenler toplandığında brüt ihracattaki yurtiçi katma değer içeriği elde edilmektedir. 7 ve 8 numaralı bileşenler toplandığında ise brüt ihracattaki yabancı katma değer elde edilmektedir.

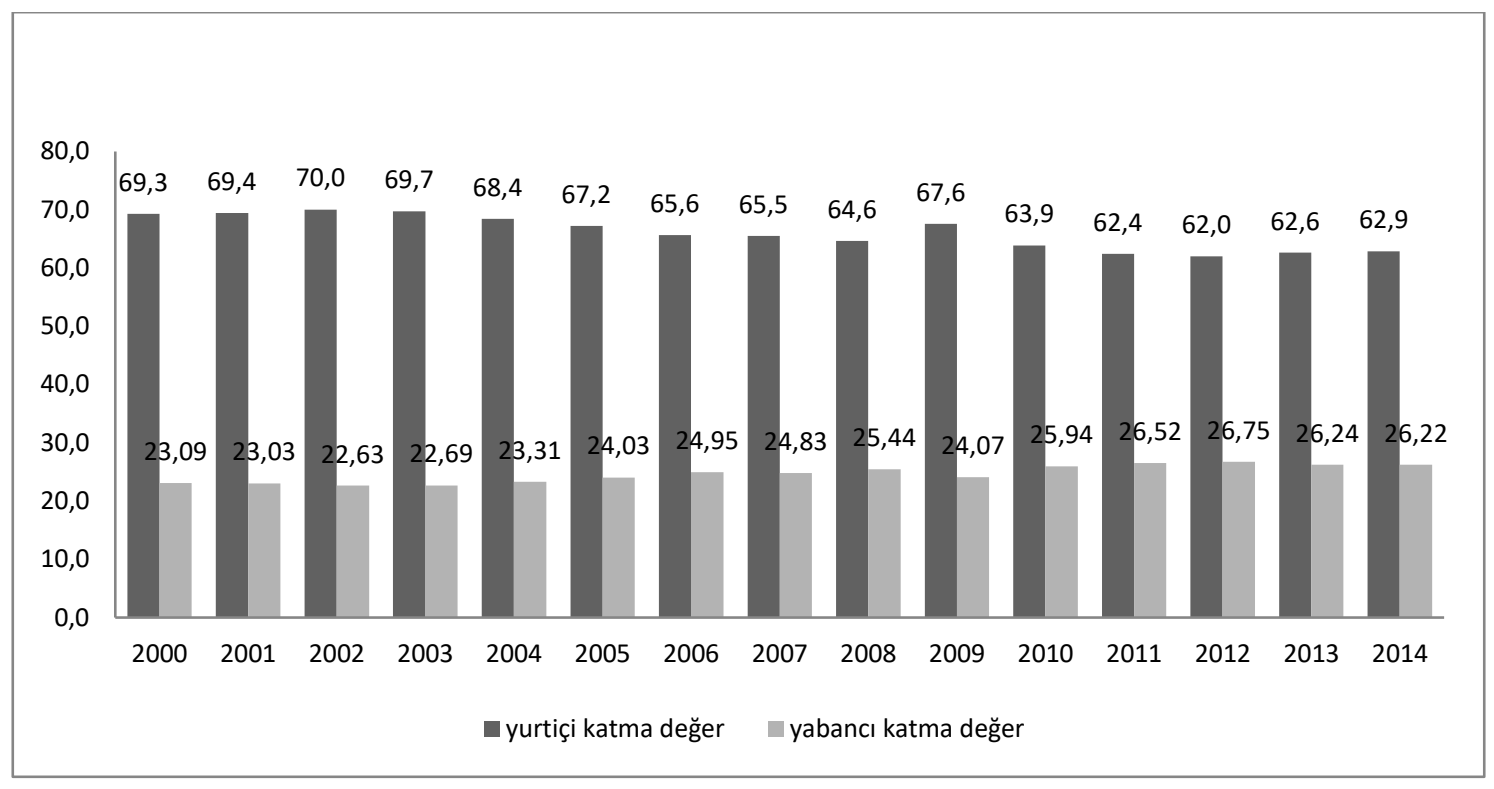

Grafik 1: Brüt İhracattaki Yurtiçi ve Yabancı Katma Değer

Kaynak: WIOD (2016) kullanılarak yazar tarafindan hesaplanmıştır.

1 numaralı grafikte Avrupa Birliği Bölgesi ülkelerinin brüt ihracattaki yurtiçi ve yabancı katma değer oranları bulunmaktadır. 2000 yılında \% 69,3 oranında gerçekleşen yurtiçi katma değer içeriği, 2002 yılında yükselerek \% 70 olarak gerçekleşmiş fakat daha sonraki yıllarda yurtiçi katma değerinde düşüş yaşanmaya başlanmıştır. Dolayısıyla, 2002 yılında en düşük seviyede olan yabancı katma değer içeriği ilerleyen yıllarda artmaya başlamıştır.

2 numaralı grafikte her ülkeye ait yurtiçi katma değerinin 2000 y1lı ve 2014 yılında gerçekleşen değerleri bulunmaktadır. Avrupa Birliği içerisinde diğer ülkelere nispeten daha çok ihracat yapan Almanya, Fransa, İspanya, İtalya ve İngiltere gibi ülkeler içerisinde yurtiçi katma değeri en yüksek olan ülkeler İngiltere ve İtalya'dır. 


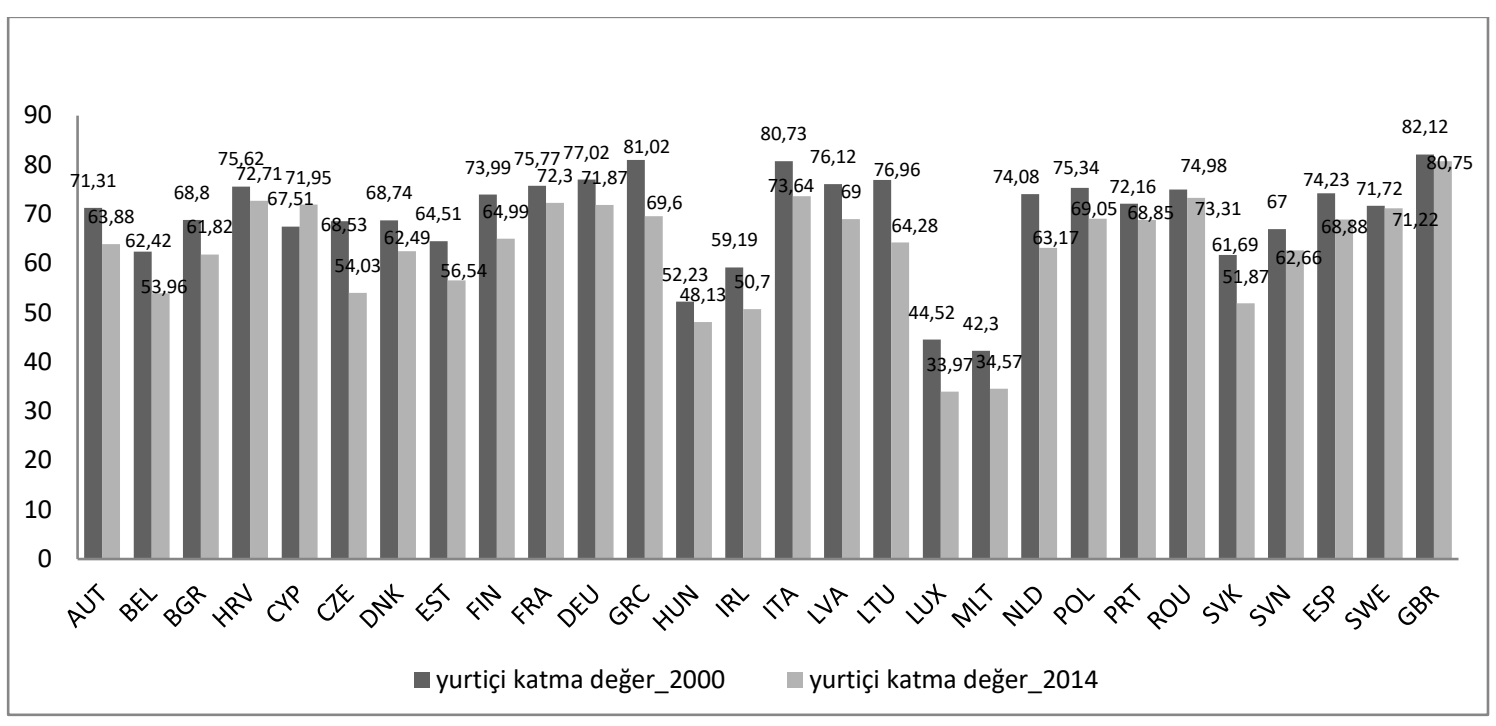

Grafik 2: Brüt İhracattaki Yurtiçi Katma Değer

Kaynak: WIOD (2016) kullanılarak yazar tarafindan hesaplanmıştır.

2014 yılında brüt ihracatta yer alan yurtiçi katma değer, 2000 yılına göre daha düşüktür. En yüksek yurtiçi katma değere sahip olan İngiltere'de, diğer ülkelere nazaran yurtiçi katma değerdeki azalma çok küçük oranda gerçekleşmiştir.

3 numaralı grafikte ülkelerin brüt ihracatlarındaki yabancı katma değer gösterilmektedir. Güçlü ihracatçılar arasında, 2000 yılında brüt ihracatta en düşük yabancı katma değer İngiltere; en yüksek yabancı katma değer İspanya'ya aittir. 2000 y1lı ve 2014 yılı karşılaştırılacak olursa; Cappariello vd. (2015)'ın Avrupa bölgesi için yaptığı çalışmasında elde ettiği sonuçlar ile paralel olarak 2000 yılında ihracatın içerdiği yabancı katma değer genel olarak daha düşüktür. 2000 yılında olduğu gibi 2014 yılında da güçlü ihracatçı ülkeler arasında en düşük yabancı katma değer İngiltere; en yüksek yabancı katma değer İspanya'ya aittir.

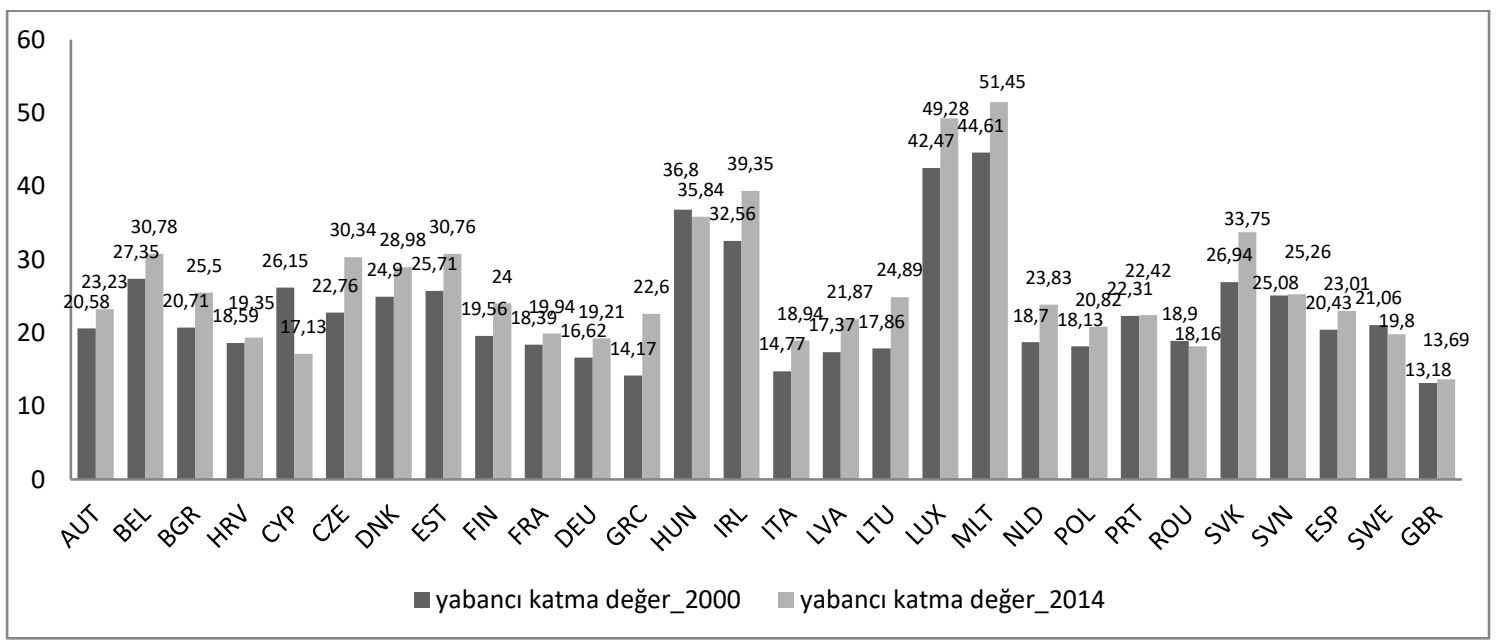

Grafik 3: Brüt İhracattaki Yabancı Katma Değer

Kaynak: WIOD (2016) kullanılarak yazar tarafindan hesaplanmıştır. 
Eğer bir ülkenin ihracatında yer alan 2 numaralı bileşenin ağırlı̆̆ı ne kadar çok ise - diğer ülkelerin yurtiçi nihai mal ve hizmet kullanımı için yapılan ara mal ihracatındaki yurtiçi katma değer- o ülke küresel üretim zincirinin daha üstünde yer alacaktır. Fakat bir ülkenin ihracatında yer alan 1 numaralı bileşenin ağırlığı ne kadar çok ise - nihai mal ve hizmet ihracatındaki yurtiçi katma değer -o ülke küresel üretim zincirinin daha altında yer alacaktır (Wang vd., 2013, s.23-28).

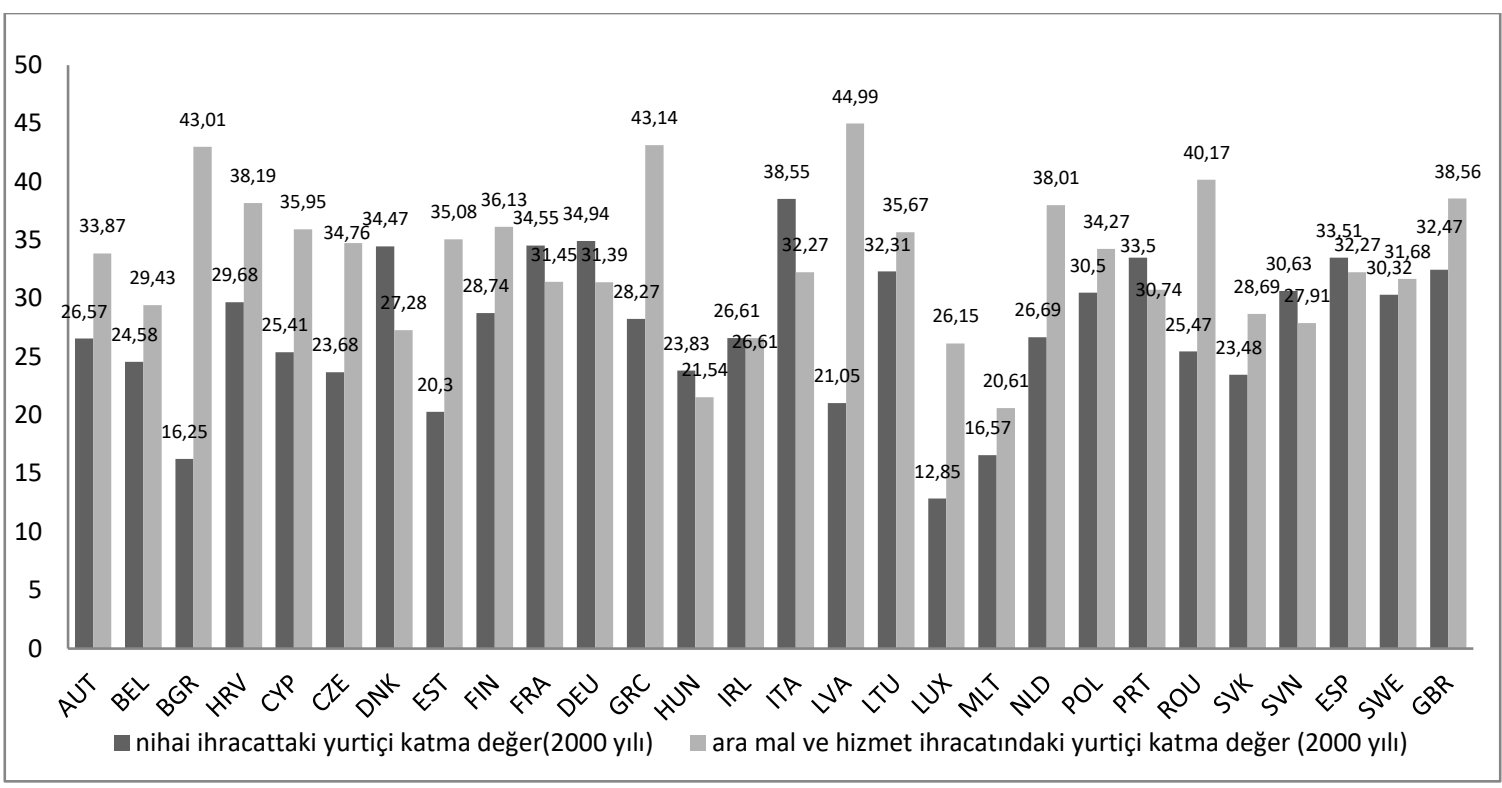

Grafik 4: Ara ve Nihai Mal ve Hizmet İhracatındaki Yurtiçi Katma Değer

Kaynak: WIOD (2016) kullanılarak yazar tarafindan hesaplanmıştır.

4 numaralı grafik, 2000 yılındaki nihai ve ara mal ve hizmet ihracatındaki katma değeri göstermektedir. Nihai mal ve hizmet ihracatında en yüksek yurtiçi katma değeri olan ülkeler sırasıyla İtalya, Almanya ve Fransa'dır. Güçlü ihracatçı ülkeler arasında ara mal ihracatındaki yurtiçi katma değerin daha yüksek olduğu ülkeler, İngiltere ve İspanya'dır. 2014 yılına bakıldığında ara mal ihracatı en yüksek ülke İngiltere iken nihai mal ihracatı en yüksek ülkeler İtalya, İspanya ve Almanya'dır. 2000 yılı ve 2014 yılı karşılaştırılacak olursa; nihai ihracattaki yurtiçi katma değer 2014 yılında azalış göstermiştir. Ara mal ihracatındaki yurtiçi katma değerin yıllara göre değişimine bakıldığında; İngiltere ve Fransa'nın ara malı ihracatındaki yurtiçi katma değeri artış göstermekte iken Almanya, İtalya ve İspanya'nın ara mal ihracatındaki yurtiçi katma değer azalmaktadır. 


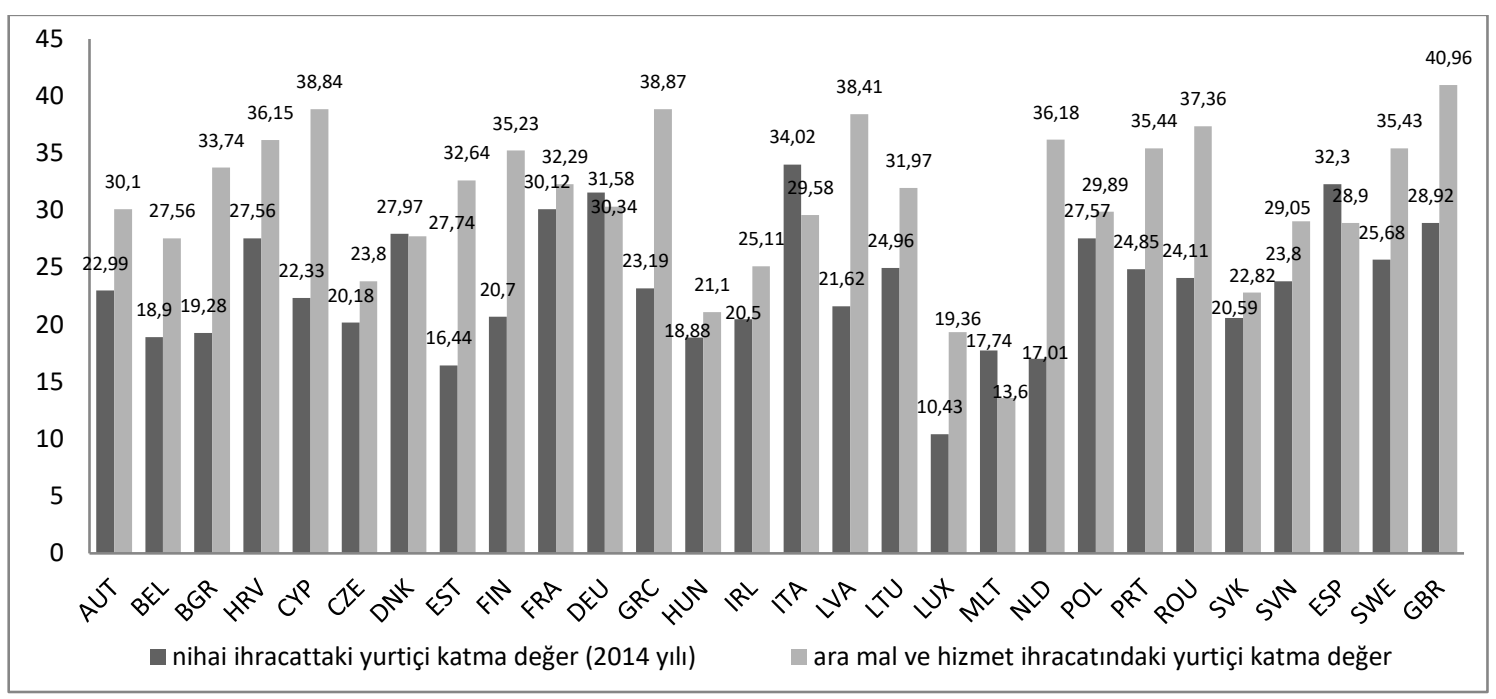

Grafik 5: Ara ve Nihai Mal ve Hizmet İhracatındaki Yurtiçi Katma Değer

Kaynak: WIOD (2016) kullanılarak yazar tarafından hesaplanmıştır.

Geliştirilen ayrıştırma metodunda yer alan 4 ve 5 numaralı bileşenlerin toplamı ülkenin ihracatının ne kadarlık bir kısmının diğer ülkelerin ihracatları aracılı̆̆ıyla geri dönerek ülkede kullanıldığını göstermektedir. 6 numaralı grafiğe bakılacak olursa en çok Almanya, İngiltere ve Fransa'nın ihracatları diğer ülkelerin ihracatları ile ülkenin kendisine geri dönmektedir.

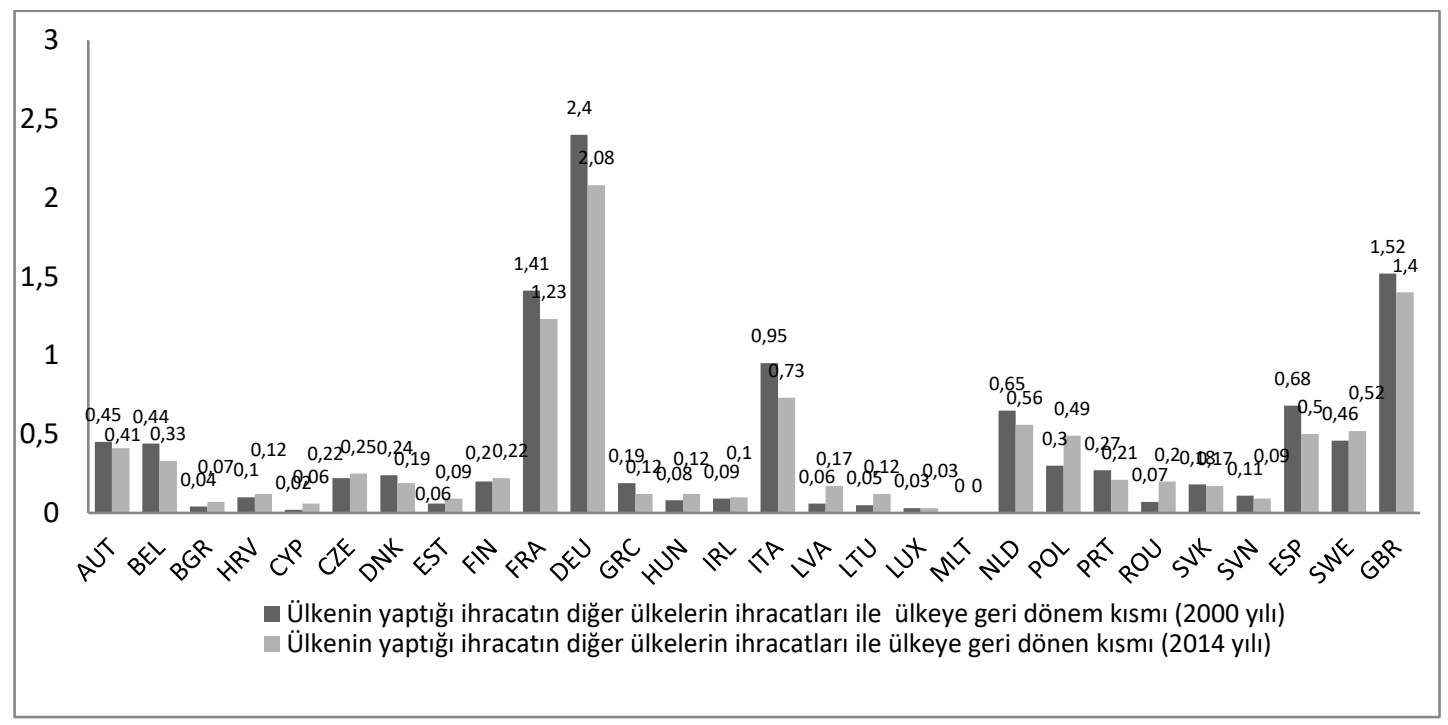

Grafik 6: Ülkenin Yaptığı İhracatın Diğer Ülkelerin İhracatları ile Ülkeye Geri Dönen Kısmı

Kaynak: WIOD (2016) kullanılarak yazar tarafindan hesaplanmıştır.

Ayrıştırma metodunda yer alan 7 numaralı bileşen, nihai mal ve hizmet ihracatındaki yabancı katma değeri; 8 numaralı bileşen, ara mal ihracatındaki yabancı katma değeri ifade etmekte idi. Bir ülkenin nihai mal ve hizmet ihracatının büyük kısmı yabancı katma değerden oluşuyorsa o ülke, ithal edilen ara mal bileşenlerini kullandıktan sonra montaj yaparak küresel değer zincirinin sonunda yer almaktadır. Bir ülkenin ara mal ihracatındaki yabancı katma değeri ne kadar büyük oranda ise ve özellikle diğer ülkelerin ihracatlarında ara malı olarak kullanılıyorsa 
o ülke, diğer ülkelerin ihracatları için ara mal üretmekte ve endüstrisini iyileştirmektedir (Wang vd., 2013, s.23-28).

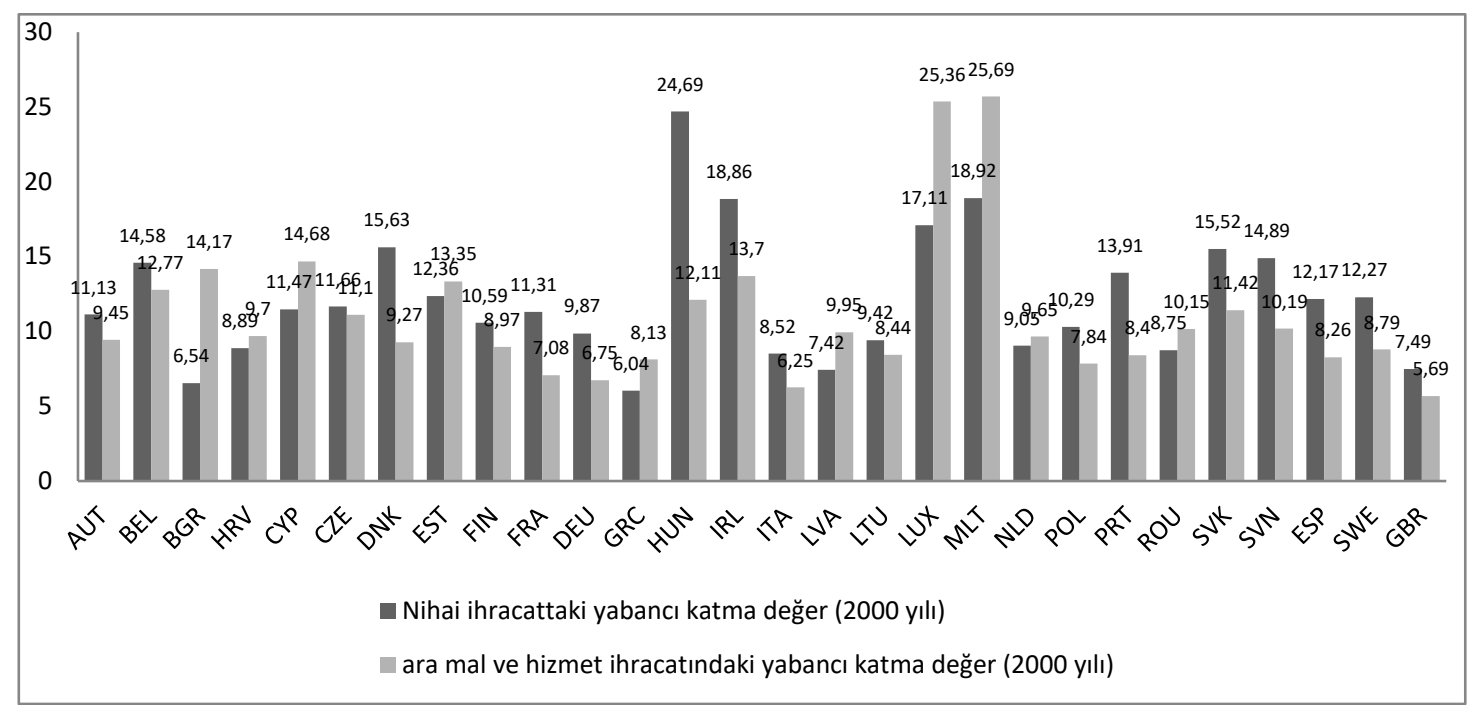

Grafik 7: Ara ve Nihai Mal ve Hizmet İhracatındaki Yabanc1 Katma Değer

Kaynak: WIOD (2016) kullanılarak yazar tarafindan hesaplanmıştır.

7 numaralı grafik, İngiltere ve İtalya'nın ara ve nihai mal ve hizmet ihracatındaki yabancı katma değerinin, Almanya, Fransa ve İspanya'ya göre daha düşük yabancı katma değer içerdiğini göstermektedir. 2014 verilerinin olduğu 8 numaralı grafikte, 2000 yılında olduğu gibi İngiltere ve İtalya'nın ara ve nihai mal ve hizmet ihracatının Almanya, Fransa ve İspanya'ya göre daha düşük yabancı katma değer içerdiği görülmektedir.

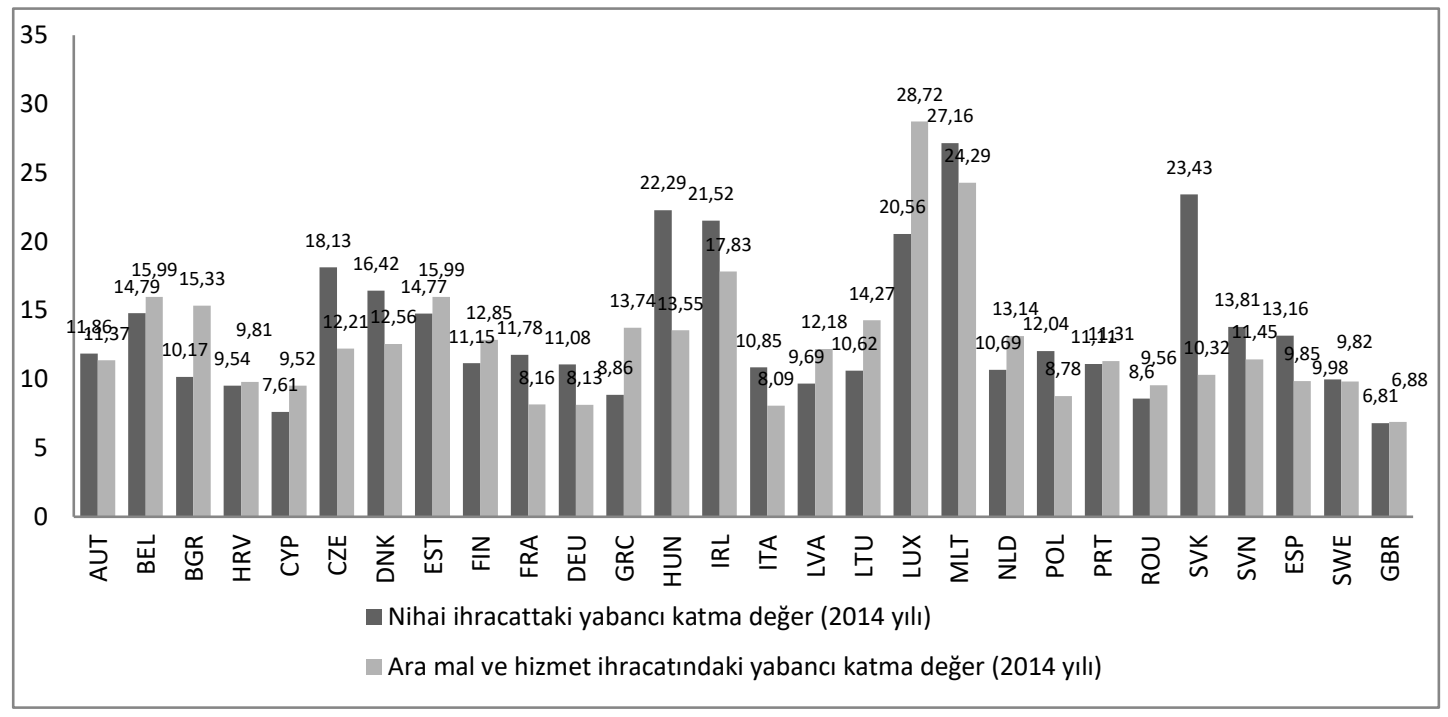

Grafik 8: Ara ve Nihai Mal ve Hizmet İhracatındaki Yabancı Katma Değer

Kaynak: WIOD (2016) kullanılarak yazar tarafından hesaplanmıştır. 


\subsection{Ampirik Analiz}

$\mathrm{Bu}$ çalışmada verimlilik, araştırma ve geliştirme yatırımları, sermaye birikimi, yabancı katma değer, işgücü verimliliği, bilgi-işlem donanım yatırımları ve iletişim yatırımlarının brüt ihracatta yer alan yurt içi katma değer üzerindeki etkisi analiz edilmektedir. Analiz, Avrupa Birliği'ne üye 21 ülke için 2000-2014 yılları için yapılmıştır. Avrupa Birliği’ne üye diğer 7 ülkenin verilerinin tam olmaması sebebi ile ampirik analizde Avusturya, Bulgaristan, Kıbrıs, Çekya, Almanya, Danimarka, Estonya, Yunanistan, Finlandiya, Fransa, İrlanda, İtalya, İspanya, Litvanya, Lüksemburg, Letonya, Hollanda, Portekiz, İsveç, Slovenya ve İngiltere yer almaktadır. İhracat alt bileşenlerinde yer alan $(1)+(2)+(3)+(4)+(5)$ numaralı bileşenler hesaplanarak ülkelerin ihracatındaki yurtiçi katma değer elde edildikten sonra ülkelerin ihracatındaki yurtiçi katma değerin belirleyicileri incelenmiştir. Analizde kullanılan model aşağıda yer verildiği gibidir.

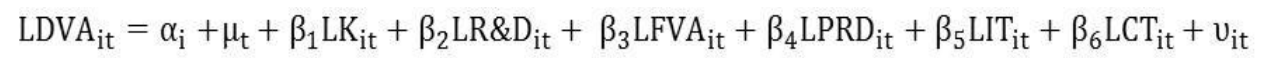

Modelde yer alan DVA, yurtiçi katma değeri; $\mathrm{K}$ sermaye stokunu; R\&D araştırma ve geliştirme yatırımlarını; FVA yabancı katma değeri; PRD işgücü verimliliğini; IT bilgi-işlem donanım yatırımlarını ve CT iletişim yatırımlarını ifade etmektedir. Modelde yer alan $\alpha_{i}$ ülke etkisi, $\mu_{\mathrm{t}}$ zaman etkisi ve $v_{\mathrm{it}}$ hata terimini tanımlamaktadır.

\subsubsection{Veri}

Analizde Dünya Girdi-Çıktı Tablosu (WIOD) 2016 revizyonlu yayını kullanılarak elde edilen yurtiçi katma değer, işgücü verimliliği, yabancı katma değer ve Avrupa Birliği KLEMS Büyüme ve Verimlilik Hesapları 2017 yayınından elde edilen araştırma ve geliştirme yatırımları, bilgi işlem donanım yatırımları, iletişim donanım yatırımları, sermaye stoku verileri kullanılmıştır. Analizde sermaye stoku, toplam sermaye stokundan araştırma geliştirme, bilgi işlem, iletişim donanımı çıkartılarak elde edilmiştir. İşgücü verimliliğine vekil olarak çıktının işgücüne oranı kullanılmıştır. Yabancı katma değer, nihai ya da ara mal ve hizmetteki yabancı katma değeri ifade etmekte olup KWW (2014) ayrıştırma metodunda yer alan 7 ve 8 numaralı denklemlerin toplanmasıyla elde edilmiştir. Analizde yer alan ticaret verileri, mal ve hizmet ticaret verilerini içermekte olup toplamda 56 sektörün verilerinin toplulaştırılmasıyla analiz gerçekleştirilmektedir. Analizde kullanılan yurtiçi ve yabancı katma değer verileri ülke bazlı olup gayrisafi yurtiçi hasıla deflatörü ile deflate edilmiştir. Diğer değişkenler sektör bazlı olup sektör fiyat seviyesi ile deflate edildikten sonra toplulaştırılmıştır. Değişkenlerin logaritması alınarak analiz gerçekleştirilmiştir.

\subsubsection{Uygulama}

Modelde yer alan verimlilik, araştırma ve geliştirme yatırımı, sermaye birikimi, yabancı katma değer, işgücü verimliliği, bilgi-işlem donanım yatırımı ve iletişim yatırımı değişkenleri ile ihracattaki katma değer arasındaki ilişkiyi sabit etki ya da rassal etki modelleri ile analiz etmeden önce diagnostik testlerin yapılması gerekmektedir.

Panel veri analizinde modele ilişkin varsayımlar ve bu varsayımlar çerçevesinde tahmin yöntemlerinin seçimi oldukça önem arz etmektedir. Bu sinamalar neticesinde uygun tahmin yöntemi seçilmiştir. Bu çerçevede Tablo 2'de oluşturulan modele ilişkin diagnostik test sonuçları sunulmaktadır. Öncelikle, klasik model (havuzlanmış en küçük kareler) ya da sabit etkiler modellerinden hangisinin geçerli olduğunu tespit etmek için bir dizi testler gerçekleştirilmiştir. Chow testi, klasik model ile sabit etkiler modellerinden hangisinin geçerli olduğunu gösterirken LM testi (Breusch-Pagan Langrange Çarpanı) de klasik model ile rassal etkiler modelinden hangisinin geçerli olduğunu test etmektedir. Buna göre, Chow testi sabit etkiler modelini işaret ederken LM testi ise sabit etkiler modelinin uygunluğuna işaret etmektedir. Son olarak da 
Hausman testiyle de sabit etkiler modeli ile rassal etkiler modelinin uygunluğu araştırılmış ve sabit etkiler modelinin bu çalışmanın tahmin yöntemi için uygun olduğu sonucuna ulaşılmıştır.

Panel veri analizinde birim boyutunun varlığ nedeniyle otokorelasyon ve değişen varyans (heteroskedastisite) sorunu sıklıkla görülmektedir. Bu bağlamda model, Woolridge otokorelasyon testi ve Breusch-Pagan değişen varyans testi ile sınanmıştır. Test sonuçları otokorelasyon ve değişen varyansl1lık sorununun olduğunu göstermektedir. Bu sebeple White (1980) tahmincisi kullanılarak dirençli standart hatalarla tahminler yapılmıştır.

Tablo 2: İhracatta Katma Değerin Belirleyicilerinin Sabit Etkiler Modeli ile Tahmini

\begin{tabular}{|c|c|}
\hline Bağımsız Değişkenler & Katsayı \\
\hline Prod & $\begin{array}{l}-.1795 \\
(-1.28)\end{array}$ \\
\hline RD & $\begin{array}{l}.1149^{*} \\
(1.82) \\
\end{array}$ \\
\hline IT & $\begin{array}{l}.0156 \\
(0.31)\end{array}$ \\
\hline CT & $\begin{array}{l}-.0823^{*} \\
(-1.88)\end{array}$ \\
\hline $\mathrm{K}$ & $\begin{array}{l}.3046^{*} \\
(1.90) \\
\end{array}$ \\
\hline FVA & $\begin{array}{c}.8314 * * * \\
(4.14)\end{array}$ \\
\hline Sabit & $\begin{array}{c}46.03 * * \\
(2.77)\end{array}$ \\
\hline $\begin{array}{c}\text { R-sq: within }=0.8482 \\
\text { between }=0.9814 \\
\text { overall }=0.9782\end{array}$ & $\begin{array}{c}F=231.64 \\
\text { Prob }>F=0.0000\end{array}$ \\
\hline Woolridge Otokorelasyon Test & $5.362 * *$ \\
\hline Breusch-Pagan Değişen VaryansTest & $24270.23 * * *$ \\
\hline Chow test & $221.88^{* * *}$ \\
\hline Breusch-Pagan LM test & $3280.07 * * *$ \\
\hline HausmanTest: & $44.09 * * *$ \\
\hline Grup Sayıs1 & 21 \\
\hline Gözlem Sayısı & 306 \\
\hline
\end{tabular}

Not: ***,**,* sırasıyla $\% 1, \% 5, \% 10$ anlamlılık düzeyinde değişkenlerin istatistiki olarak anlamlı olduğunu ifade etmektedir. Parantez içindeki t değerleri (White (1980) tahmincisi kullanılarak) dirençli standart hata kullanılarak oluşturulmuştur.

Analiz sonuçları, ihracata oranı yükseliş trendine sahip olan yabancı katma değerin yurtiçi katma değeri büyük oranda etkilediğini göstermektedir. Ülkeler, ihracat yapmak için daha çok yabancı katma değere ihtiyaç duymakta ya da dış kaynak kullanımına başvurmaktadır. Bu sonuç tanımlayıcı analiz ile elde edilen, ihracat bileşenlerinde yer alan yabancı katma değerin arttığı sonucu ile örtüşmektedir. Yabancı katma değerde gerçekleşen \% 1'lik artış, yurtiçi katma değeri $\% 0.83$ oranında artırmaktadır. Ulaşılan bir başka sonuç, sermaye stokundaki \%1'lik artışın yurtiçi katma değeri \% 0.30 oranında artırdı̆̆ıdır. Aynı şekilde araştırma ve geliştirme yatırımları beklendiği üzere yurtiçi katma değeri pozitif etkilemektedir. Sermaye stokunun, araştırma ve geliştirme yatırımlarının yurtiçi katma değeri pozitif etkilediği sonucu, Yu ve Zhechong (2018) Çin için yaptığı analiz sonuçları ile paraleldir.

Diğer sonuçlar, iletişim yatırımlarının yurtiçi katma değeri negatif şekilde etkilediği, bilgiişlem yatırımları ve verimliliğin katma değeri istatiksel olarak etkilemediği yönündedir. Analizin sektörlerin toplulaştırılmasıyla gerçekleştirilmesinden kaynaklı olarak anlamlı bir ilişkinin elde edilmemiş olduğu düşünülmektedir. 


\section{SONUÇ}

Yeni uluslararası işbölümü ile üretim süreçleri, parçalara ayrılarak her bir mal ve hizmetin üretimi, o mal ve hizmetin üretiminin farklı aşamalarında uzmanlaşan ülkeler tarafindan gerçekleşmektedir (UNCTAD, 2013). Bu üretim organizasyonu, dış ticaret ve yatırımlar üzerinde etkili olduğundan küresel değer zincirinin hesaplanması önem arz etmektedir. Bu bağlamda, çalışmada KWW (2014) brüt ihracat ayrıştırma metodu kullanılmıştır. Küresel değer zincirinin ölçümü için geliştirilen diğer ölçüm yöntemlerinde katma değer net olarak ifade edilmeyip ülkelerin brüt ihracatları çift sayım problemini barındırmaktadır. KWW (2014) ayrıştırma metodunda brüt ihracat, 9 ayrı bileşene ayrıştırılarak ülkelerin ihracatlarındaki yurtiçi katma değer, yabancı katma değer ve brüt ihracatın çift sayılan kısımları ayrı ayrı gösterilmektedir.

Bu çalışmanın tanımlayıcı analiz kısmında, 2000-2014 yıllarını kapsayan dönem için 28 Avrupa Birliği ülkesinin ihracatları, ayrıştırma metodu ile 9 ayrı bileşene ayrılmıştır. Türkçe literatürde daha önce kullanılmayan KWW (2014) metodunun kullanılması ile bu çalışma literatüre katkı sağlayacaktır. Bütün Avrupa Birliği ülkelerinin ihracat bileşenlerinin ayrı ayrı hesaplanarak, ülkelerin küresel değer zincirindeki konumunun daha detaylı bakıldığı çalışmanın olmaması, bu çalışmanın literatüre diğer katkısını oluşturmaktadır. Tanımlayıcı analiz ile ihracattaki yurtiçi katma değer, brüt ihracattaki yabancı katma değer, nihai ve ara malı ihracatındaki yabancı ve yurtiçi katma değer, bir ülke tarafından yapılan ihracatın diğer ülkelerin ihracatında kullanılıp o ülkeye geri dönen kısmı hesaplanarak ülkeler bazında karşılaştırma yapılmıştır. Ayrıca, bütün ülkelerin verilerinin toplulaştırılarak Avrupa Birliği'nin geneli için çıkarımlar da yapılmıştır. Tanımlayıcı analizin sonuçları, 2000 yılına kıyasla 2014 yılında yurtiçi katma değerin azaldığını göstermektedir. Hem 2000 hem de 2014 yılında en yüksek yurtiçi katma değer, İngiltere tarafindan elde edilmiş olup diğer ülkelere nazaran bu ülkede yurtiçi katma değerdeki düşme çok küçük oranda gerçekleşmiştir. Tanımlayıcı analizin bir diğer sonucu, 2014 yılında ihracattaki yabancı katma değerin azalmış olduğudur. Hem 2000 hem 2014 yılında Avrupa Birliği Bölgesi içerisinde diğer Avrupa Birliği ülkelerine nispeten daha çok ihracat yapan ülkelerden, brüt ihracatta en düşük yabancı katma değeri olan ülke İngiltere; en yüksek yabancı katma değeri olan ülke İspanya'dır. Çalışmanın sonucunda ayrıca, 2000 yılında nihai mal ve hizmet ihracatında en yüksek yurtiçi katma değeri olan ülkelerin sırasıyla İtalya, Almanya ve Fransa; ara mal ihracatındaki yurtiçi katma değerin daha yüksek olduğu ülkelerin ise İngiltere ve İspanya olduğu sonucuna ulaşılmaktadır. 2014 yılında ara mal ihracatında yurtiçi katma değeri en yüksek ülke, İngiltere iken nihai mal ihracatında yurtiçi katma değeri en yüksek ülkeler sırasıyla İtalya, İspanya ve Almanya'dır. Bir diğer analiz sonucu, en çok Almanya, İngiltere ve Fransa'nın ihracatlarının diğer ülkelerin ihracatlarında ara malı olarak kullanılarak ülkenin kendisine geri döndüğünü göstermektedir. Sonuçlar ayrıca, hem 2000 hem de 2014 yılında İngiltere ve İtalya'nın ara ve nihai mal ve hizmet ihracatının, Almanya, Fransa ve İspanya'ya göre daha düşük yabanc1 katma değer içerdiğini göstermektedir. 2000 yılında İngiltere'nin nihai ihracatındaki yabancı katma değer, ara mal ihracatındaki yabancı katma değerden büyük iken 2014 yılında, ara mal ihracatındaki yabancı katma değer daha yüksektir. Nihai ihracattaki yabancı katma değerin azalmakta ve ara mal ihracatındaki yabancı katma değeri artmakta olduğu sonucu, İngiltere'nin diğer Avrupa Birliği ülkelerine nazaran küresel değer zincirinde daha iyi konumlandığını ve 2000 yılına kıyasla 2014 yılında küresel değer zincirindeki konumunu iyileştirdiğini göstermektedir. Dolayısıyla elde edilen bu tanımlayıcı analiz sonuçları, ithal edilen ara malı artışı ve artan dikey uzmanlaşma ile üretimdeki parçalanmanın arttı̆̆ına işaret etmektedir. Elde edilen bu bulgu, 2000 yılından itibaren değer zincirinin küresellik niteliğini iyice pekiştirdiğini kanıtlamaktadır.

Analizin ikinci kısmında gerçekleştirilen ampirik analiz sonuçları, yabancı katma değerdeki \% 1'lik artışın yurtiçi katma değeri \% 0.83 oranında arttırdığını göstermektedir. Dolayısıyla, ülkeler ihracat yapmak için daha çok yabancı katma değere ihtiyaç duymaktadır. Ampirik analiz sonuçları beklentilere paralel olarak sermaye stokundaki \%1'lik artışın yurtiçi katma değeri \% 0.30 oranında artırdığını; araştırma ve geliştirme yatırımlarındaki \%1'lik artışın yurtiçi katma 
değeri \% 0.11 oranında arttırdığını göstermektedir. Bilgi işlem yatırımları ve verimlilik istatistiksel olarak anlamlı değildir ve iletişim yatırımları istatistiksel olarak anlamlı fakat yurtiçi katma değeri negatif olarak etkilemektedir. Analizin ülke bazında ayrı ayrı yapılması halinde ya da sektör bazlı verilerin kullanılması halinde ampirik analiz sonuçlarının daha ikna edici olacağı beklenmektedir.

Sonuç olarak, Avrupa Birliği ülkelerinin küresel değer zincirine entegrasyonunun artırılması için üretimde yurtiçi katma değerin yükseltilmesi gerekmektedir. Küresel değer zincirinde daha aşağıda konumlanan ülkelerin daha kaliteli mallar üretilerek ürün yelpazesinin küresel pazarda yüksek talep gören ürünleri kapsayacak şekilde genişleterek daha teknoloji yoğunluklu hale getirmesi gerekmektedir.

\section{KAYNAKÇA}

Amador, J., \& Cabral, S. (2016). Global value chains: A survey of drivers and measures. Journal of Economic Surveys, 30(2), 278-301.

Amador, J., Cappariello, R., \& Stehrer, R. (2015). Foreign value added in Eurozone exports. Joao Amador ve Filippo di Mauro (Ed.).In The age of global value chains: Maps and policy issues, 25-35.

Benkovskis, K. ; Wörz, J. (2016). The interpretation of changes in global market shares: Adding the global value chain dimension. Joao Amador ve Filippo di Mauro (Ed.).In The age of global value chains: Maps and policy issues,148-161

Cappariello, R., Stehrer, R., \& Amador, J. (2014). Global Value Chains: A View From the Euro Area (No. w201412).

Daudin, G., Rifflart, C., \& Schweisguth, D. (2011). Who produces for whom in the world economy?. Canadian Journal of Economics/Revue canadienne d'économique, 44(4), 1403-1437.

Donofrio, D. (2018). Essays on Empirical International Economics.

EUKLEMS (2017). EU KLEMS Growth and Productivity Accounts. http://www.euklems.net/

Feenstra, R. C., \& Hanson, G. H. (1996). Globalization, outsourcing, and wage inequality (No. w5424). Natronla Bureau of Economic Research.

Feenstra, R. C., \& Hanson, G. H. (1999). The impact of outsourcing and high-technology capital on wages: estimates for the United States, 1979-1990. The Quarterly Journal of Economics, 114(3), 907-940.

Hummels, D., Ishii, J., \& Yi, K. M. (2001). The nature and growth of vertical specialization in world trade. Journal of international Economics, 54(1), 75-96.

Johnson, R. C., \& Noguera, G. (2012). Accounting for intermediates: Production sharing and trade in value added. Journal of international Economics, 86(2), 224-236.

Koopman, R., Wang, Z., \& Wei, S. J. (2014). Tracing value-added and double counting in gross exports. American Economic Review, 104(2), 459-94.

Solaz, M. (2018). Value added and participation in global value chains: The case of Spain. The World Economy, 41(10), 2804-2827.

Timmer, M. P., Los, B., Stehrer, R., \& De Vries, G. J. (2013). Fragmentation, incomes and jobs: an analysis of European competitiveness. Economic policy, 28(76), 613-661.

UNCTAD, (2013). World Investment Report 2013 Global Value Chains: Investment and Trade for Development. United Nations, New York and Geneva.

Wang, Z., Wei, S. J., \& Zhu, K. (2013). Quantifying international production sharing at the bilateral and sector levels (No. w19677). National Bureau of Economic Research.

WIOD (2016). World Input Output Database. http://www.wiod.org

WTO (2008). World Trade Report 2008-Trade in a Globalizing World Trade Organization (WTO). Geneva, Switzerland.

Yu, C., \& Luo, Z. (2018). What are China's real gains within global value chains? Measuring domestic value added in China's exports of manufactures. China Economic Review, 47, 263-273. 


\section{EKLER}

KWW (2014) brüt ihracat ayrıştırma metodunda brüt ihracat, 9 ayrı bileşene ayrılmaktadır. Aşağıda yer alan Tablo 1'de, 28 Avrupa Birliği ülkesinin verilerinin toplulaştırılmasının ardından KWW (2014) ayrıştırma metodu kullanılarak elde edilen ihracat bileşenlerinin 15 yıllık değerleri bulunmaktadir.

Tablo 1: KWW (2014) Yöntemi ile Avrupa Birliği Ülkelerinin Toplam Brüt İhracatının Ayrıştırılması

\begin{tabular}{|c|c|c|c|c|c|c|c|c|c|}
\hline YIL & KWW 1 & KWW 2 & KWW 3 & KWW 4 & KWW 5 & KWW 6 & KWW 7 & KWW 8 & KWW 9 \\
\hline 2000 & 27.35 & 33.207739 & 8.3478273 & 0.229642 & 0.173 & 0.1635708 & 12.1196 & 10.9753 & 7.4342592 \\
\hline 2001 & 27.72 & 32.822489 & 8.4991107 & 0.2282192 & 0.166 & 0.1567891 & 12.162761 & 10.8681 & 7.3801581 \\
\hline 2002 & 27.89 & 33.153214 & 8.5892857 & 0.2317857 & 0.170 & 0.1617857 & 11.895714 & 10.7332 & 7.1728571 \\
\hline 2003 & 27.59 & 33.154641 & 8.5615203 & 0.2425026 & 0.179 & 0.1696447 & 11.855484 & 10.8365 & 7.4057936 \\
\hline 2004 & 26.77 & 32.513563 & 8.7204506 & 0.2489312 & 0.182 & 0.1871449 & 12.182988 & 11.1226 & 8.0708008 \\
\hline 2005 & 26.65 & 31.613666 & 8.5447649 & 0.2425035 & 0.183 & 0.1946456 & 12.562679 & 11.4698 & 8.5386934 \\
\hline 2006 & 25.85 & 30.776374 & 8.573398 & 0.2425052 & 0.182 & 0.2046472 & 13.120638 & 11.8324 & 9.2209119 \\
\hline 2007 & 24.89 & 31.515416 & 8.687935 & 0.2485634 & 0.188 & 0.2171359 & 12.959583 & 11.8714 & 9.418983 \\
\hline 2008 & 24.44 & 31.265625 & 8.4863073 & 0.2389252 & 0.186 & 0.2157112 & 13.062671 & 12.3748 & 9.7277182 \\
\hline 2009 & 25.69 & 33.345357 & 8.1504445 & 0.2242881 & 0.179 & 0.1885734 & 12.317275 & 11.7505 & 8.1579445 \\
\hline 2010 & 23.78 & 31.226406 & 8.5211627 & 0.1817877 & 0.149 & 0.1789305 & 13.420501 & 12.5223 & 10.015822 \\
\hline 2011 & 23.23 & 30.304113 & 8.512652 & 0.2185753 & 0.170 & 0.2271469 & 13.739174 & 12.7817 & 10.816979 \\
\hline 2012 & 22.86 & 30.329069 & 8.4345826 & 0.2053557 & 0.162 & 0.2242841 & 13.66276 & 13.0885 & 11.037064 \\
\hline 2013 & 22.83 & 31.07888 & 8.3376787 & 0.2125046 & 0.168 & 0.2435766 & 13.245641 & 12.9913 & 10.887376 \\
\hline 2014 & 23.37 & 30.802363 & 8.318988 & 0.2146444 & 0.163 & 0.2360731 & 13.517239 & 12.7037 & 10.678648 \\
\hline
\end{tabular}

Kaynak: WIOD (2016) kullanılarak yazar tarafindan hesaplanmıştır.

Aşağıda yer alan tablolarda, Avrupa Birliği ülkelerinin 2000-2014 yıllarını kapsayan ihracat bileşenlerinin sadece 2000 yılına ve 2014 yılına ait verilerine yer verilmiştir. Tablo 2'de Avrupa Birliği ülkelerinin 2000 yılına ait ihracat bileşenleri bulunmaktadır. 
Tablo 2: Avrupa Birliği Ülkelerinin KWW (2014) Yöntemi ile Brüt İhracatının Ayrıştırılması

\section{Yilı}

\begin{tabular}{|c|c|c|c|c|c|c|c|c|c|c|c|}
\hline YIL & ÜLKE & $\begin{array}{c}\text { ÜLKE } \\
\text { KODU }\end{array}$ & KWW 1 & KWW 2 & KWW 3 & KWW 4 & KWW 5 & KWW 6 & KWW 7 & KWW 8 & $\begin{array}{c}\text { KWW } \\
9\end{array}$ \\
\hline 2000 & AUT & 40 & 26.6 & 33.9 & 10.42 & 0.29 & 0.16 & 0.22 & 11.1 & 9.45 & 7.87 \\
\hline 2000 & BEL & 56 & 24.6 & 29.4 & 7.97 & 0.26 & 0.18 & 0.38 & 14.6 & 12.8 & 9.84 \\
\hline 2000 & BGR & 100 & 16.3 & 43 & 9.5 & 0.01 & 0.03 & 0.01 & 6.54 & 14.2 & 10.48 \\
\hline 2000 & HRV & 191 & 29.7 & 38.2 & 7.65 & 0.05 & 0.05 & 0.03 & 8.89 & 9.7 & 5.77 \\
\hline 2000 & CYP & 196 & 25.4 & 36 & 6.13 & 0.01 & 0.01 & 0.01 & 11.5 & 14.7 & 6.34 \\
\hline 2000 & CZE & 203 & 23.7 & 34.8 & 9.87 & 0.11 & 0.11 & 0.12 & 11.7 & 11.1 & 8.62 \\
\hline 2000 & DNK & 208 & 34.5 & 27.3 & 6.75 & 0.12 & 0.12 & 0.21 & 15.6 & 9.27 & 6.16 \\
\hline 2000 & EST & 233 & 20.3 & 35.1 & 9.07 & 0.03 & 0.03 & 0.02 & 12.4 & 13.4 & 9.77 \\
\hline 2000 & FIN & 246 & 28.7 & 36.1 & 8.92 & 0.11 & 0.09 & 0.11 & 10.6 & 8.97 & 6.35 \\
\hline 2000 & FRA & 251 & 34.6 & 31.5 & 8.36 & 0.81 & 0.6 & 0.5 & 11.3 & 7.08 & 5.35 \\
\hline 2000 & DEU & 276 & 34.9 & 31.4 & 8.29 & 1.45 & 0.95 & 0.95 & 9.87 & 6.75 & 5.4 \\
\hline 2000 & GRC & 300 & 28.3 & 43.1 & 9.42 & 0.11 & 0.08 & 0.02 & 6.04 & 8.13 & 4.79 \\
\hline 2000 & HUN & 348 & 23.8 & 21.5 & 6.78 & 0.04 & 0.04 & 0.08 & 24.7 & 12.1 & 10.88 \\
\hline 2000 & IRL & 372 & 26.6 & 26.6 & 5.88 & 0.06 & 0.03 & 0.08 & 18.9 & 13.7 & 8.16 \\
\hline 2000 & ITA & 381 & 38.6 & 32.3 & 8.96 & 0.55 & 0.4 & 0.23 & 8.52 & 6.25 & 4.29 \\
\hline 2000 & LVA & 428 & 21.1 & 45 & 10.02 & 0.03 & 0.03 & 0.01 & 7.42 & 9.95 & 6.51 \\
\hline 2000 & LTU & 440 & 32.3 & 35.7 & 8.93 & 0.03 & 0.02 & 0.01 & 9.42 & 8.44 & 5.17 \\
\hline 2000 & LUX & 442 & 12.9 & 26.2 & 5.49 & 0.02 & 0.01 & 0.07 & 17.1 & 25.4 & 12.93 \\
\hline 2000 & MLT & 470 & 16.6 & 20.6 & 5.12 & 0 & 0 & 0.01 & 18.9 & 25.7 & 13.07 \\
\hline 2000 & NLD & 528 & 26.7 & 38 & 8.73 & 0.37 & 0.28 & 0.4 & 9.05 & 9.65 & 6.82 \\
\hline 2000 & POL & 616 & 30.5 & 34.3 & 10.27 & 0.14 & 0.16 & 0.1 & 10.3 & 7.84 & 6.44 \\
\hline 2000 & PRT & 620 & 33.5 & 30.7 & 7.65 & 0.14 & 0.13 & 0.05 & 13.9 & 8.4 & 5.47 \\
\hline 2000 & ROU & 642 & 25.5 & 40.2 & 9.27 & 0.03 & 0.04 & 0.03 & 8.75 & 10.2 & 6.09 \\
\hline 2000 & SVK & 703 & 23.5 & 28.7 & 9.34 & 0.09 & 0.09 & 0.08 & 15.5 & 11.4 & 11.28 \\
\hline 2000 & SVN & 705 & 30.6 & 27.9 & 8.35 & 0.06 & 0.05 & 0.05 & 14.9 & 10.2 & 7.87 \\
\hline 2000 & ESP & 724 & 33.5 & 32.3 & 7.77 & 0.34 & 0.34 & 0.21 & 12.2 & 8.26 & 5.13 \\
\hline 2000 & SWE & 752 & 30.3 & 31.7 & 9.26 & 0.26 & 0.2 & 0.27 & 12.3 & 8.79 & 6.94 \\
\hline 2000 & GBR & 826 & 32.5 & 38.6 & 9.57 & 0.91 & 0.61 & 0.32 & 7.49 & 5.69 & 4.37 \\
\hline
\end{tabular}

Kaynak: WIOD (2016) kullanılarak yazar tarafindan hesaplanmıştır. 
Tablo 3'de, Avrupa Birliği ülkelerinin 2014 yılına ait ihracat bileşenleri bulunmaktadır.

Tablo 3: Avrupa Birliği Ülkelerinin KWW (2014) Yöntemi ile Brüt İhracatının Ayrıştırılması

\section{4 yılı}

\begin{tabular}{|c|c|c|c|c|c|c|c|c|c|c|c|}
\hline YIL & ÜLKE & $\begin{array}{l}\text { ÜLKE } \\
\text { KODU }\end{array}$ & KWW 1 & KWW 2 & KWW 3 & KWW 4 & KWW 5 & KWW 6 & KWW 7 & KWW 8 & KWW 9 \\
\hline 2014 & AUT & 40 & 22.99 & 30.1 & 10.38 & 0.25 & 0.16 & 0.29 & 11.9 & 11.37 & 12.61 \\
\hline 2014 & BEL & 56 & 18.9 & 27.56 & 7.17 & 0.18 & 0.15 & 0.39 & 14.8 & 15.99 & 14.84 \\
\hline 2014 & BGR & 100 & 19.28 & 33.74 & 8.73 & 0.04 & 0.03 & 0.03 & 10.2 & 15.33 & 12.65 \\
\hline 2014 & HRV & 191 & 27.56 & 36.15 & 8.88 & 0.06 & 0.06 & 0.05 & 9.54 & 9.81 & 7.9 \\
\hline 2014 & CYP & 196 & 22.33 & 38.84 & 10.72 & 0.02 & 0.04 & 0.04 & 7.61 & 9.52 & 10.87 \\
\hline 2014 & CZE & 203 & 20.18 & 23.8 & 9.8 & 0.15 & 0.1 & 0.33 & 18.1 & 12.21 & 15.31 \\
\hline 2014 & DNK & 208 & 27.97 & 27.74 & 6.59 & 0.1 & 0.09 & 0.17 & 16.4 & 12.56 & 8.37 \\
\hline 2014 & EST & 233 & 16.44 & 32.64 & 7.37 & 0.05 & 0.04 & 0.09 & 14.8 & 15.99 & 12.59 \\
\hline 2014 & FIN & 246 & 20.7 & 35.23 & 8.84 & 0.1 & 0.12 & 0.12 & 11.2 & 12.85 & 10.89 \\
\hline 2014 & FRA & 251 & 30.12 & 32.29 & 8.66 & 0.67 & 0.56 & 0.46 & 11.8 & 8.16 & 7.3 \\
\hline 2014 & DEU & 276 & 31.58 & 30.34 & 7.87 & 1.24 & 0.84 & 1.39 & 11.1 & 8.13 & 7.52 \\
\hline 2014 & $\mathrm{GRC}$ & 300 & 23.19 & 38.87 & 7.42 & 0.06 & 0.06 & 0.04 & 8.86 & 13.74 & 7.77 \\
\hline 2014 & HUN & 348 & 18.88 & 21.1 & 8.03 & 0.07 & 0.05 & 0.16 & 22.3 & 13.55 & 15.86 \\
\hline 2014 & IRL & 372 & 20.5 & 25.11 & 4.99 & 0.06 & 0.04 & 0.13 & 21.5 & 17.83 & 9.83 \\
\hline 2014 & ITA & 381 & 34.02 & 29.58 & 9.31 & 0.39 & 0.34 & 0.32 & 10.9 & 8.09 & 7.11 \\
\hline 2014 & LVA & 428 & 21.62 & 38.41 & 8.8 & 0.09 & 0.08 & 0.1 & 9.69 & 12.18 & 9.04 \\
\hline 2014 & LTU & 440 & 24.96 & 31.97 & 7.23 & 0.09 & 0.03 & 0.05 & 10.6 & 14.27 & 10.76 \\
\hline 2014 & LUX & 442 & 10.43 & 19.36 & 4.15 & 0.02 & 0.01 & 0.08 & 20.6 & 28.72 & 16.67 \\
\hline 2014 & MLT & 470 & 17.74 & 13.6 & 3.23 & 0 & 0 & 0.03 & 27.2 & 24.29 & 13.94 \\
\hline 2014 & NLD & 528 & 17.01 & 36.18 & 9.42 & 0.33 & 0.23 & 0.8 & 10.7 & 13.14 & 12.2 \\
\hline 2014 & POL & 616 & 27.57 & 29.89 & 11.1 & 0.27 & 0.22 & 0.27 & 12 & 8.78 & 9.87 \\
\hline 2014 & PRT & 620 & 24.85 & 35.44 & 8.35 & 0.13 & 0.08 & 0.09 & 11.1 & 11.31 & 8.64 \\
\hline 2014 & ROU & 642 & 24.11 & 37.36 & 11.64 & 0.1 & 0.1 & 0.07 & 8.6 & 9.56 & 8.46 \\
\hline 2014 & SVK & 703 & 20.59 & 22.82 & 8.29 & 0.11 & 0.06 & 0.2 & 23.4 & 10.32 & 14.18 \\
\hline 2014 & SVN & 705 & 23.8 & 29.05 & 9.72 & 0.06 & 0.03 & 0.08 & 13.8 & 11.45 & 12 \\
\hline 2014 & ESP & 724 & 32.3 & 28.9 & 7.18 & 0.27 & 0.23 & 0.26 & 13.2 & 9.85 & 7.84 \\
\hline 2014 & SWE & 752 & 25.68 & 35.43 & 9.59 & 0.31 & 0.21 & 0.28 & 9.98 & 9.82 & 8.71 \\
\hline 2014 & GBR & 826 & 28.92 & 40.96 & 9.47 & 0.79 & 0.61 & 0.29 & 6.81 & 6.88 & 5.27 \\
\hline
\end{tabular}

Kaynak: WIOD (2016) kullanılarak yazar tarafindan hesaplanmıștır. 


\section{Extended Summary}

\section{The Determinants of Domestic Value Added in Exports of European Union Countries}

The reduction of transportation, information and communication technologies cost, political and economic barriers and improvements in technology led to change the structure of production of goods and services. International production, trade and investments are increasingly organized within so-called global value chains (GVCs) where the different stages of the production process are located across different countries. GVCs have become a dominant feature of world trade. The whole process of production, from raw materials to finished products, is carried out wherever the necessary skills and materials are available at competitive cost and quality (OECD, 2013).

The aim of this study is to examine the participation of European countries in global value chains between 2000 and 2014 from the perspective of trade in value added and vertical specialization using World Input Output Database (WIOD). The literature on vertical specialization, the import content of exports, focuses on the degree of interconnectedness of countries in global production chains trade in intermediate inputs. The first measure of vertical specialization, proposed by Hummels, Ishii, and Yi (2001), refers to the imported foreign content in a country's exports based on a country's Input-Output (IO) table. The second measure, also proposed by HIY (2001), is the value of intermediate exports sent indirectly through third countries to final destinations. Third measure is the value of a country's exported goods that are used as imported inputs by rest of the world to produce final goods that are shipped back to home. This measure is proposed by Daudin, Rifflart and Schweisguth (2011). Fourth measure of vertical specialization, proposed by Johnson and Noguera (2012), refers to value added exports which is value added produced in source country and absorded in destination country. First three measures involve values that are included in more than one country's gross exports.

In this research, gross exports accounting method of Koopman, Wang and Wei (2014) is used for measurement of global value chains. In this method, vertical specialization measure is generalized without the restrictive assumption made by HIY (2001), no two-way trade in intermediate goods. Because the international trade statistics contain the value added which is acquired by different countries because of carrying out different stages of production by different countries and crossing borders more than once of intermediate inputs, the international trade statistics have double counting problem (Koopman, Wang and Wei, 2014: 459-60). This problem is solved by decomposing of gross exports into various components including exports of value added, domestic value added that returns home, foreign value added, and other additional double counted terms. That is, gross accounting framework establishes a relationship between valueadded measures of trade and official trade statistics.

In the descriptive analysis, World Input Output Tables (WIOT) are used. WIOT cover 43 countries (28 European countries and other 15 other major countries) and a model for the rest of the world for the period 2000-2014. The data for 56 sectors are classified according to the International Standard Industrial classification revision 4 (ISIC Rev.4). To examine the participation of GVCs of European countries, firstly the domestic value added, foreign value added and other additional double counted terms of exports of countries are calculated. One of the conclusion of the analysis is that domestic value added of exports of countries decrease in 2014. The highest domestic value added of exports belongs to the United Kingdom in both 2000 and 2014. Also, the decrease in the domestic value added of exports occurs slightly in the United Kingdom. The other conclusion of the descriptive analysis indicates that foreign value added of exports of countries increase in 2014. The country has the lowest foreign value added of export is 
the United Kingdom and the country has the highest foreign value added of export is Spain in the largest exporting countries in European countries in both 2000 and 2014.

In the empirical analysis, WIOD and European Union Klems database is used. European Union Klems Growth and Productivity Accounts Database is based on the NACE 2 industry classification and the new European system of national accounts up to 2015 for all 28 member states of the European Union. The data of domestic value added, foreign value added is obtained using WIOD. European Union Klems database is used for the data of productivity, research and development investments, capital accumulation, computing equipment investment and communication equipment. In this part of the analysis, the effect of productivity, research and development investments, capital accumulation, foreign value added, computing equipment investment and communication equipment on the domestic value added of export is analyzed. For the empirical analysis, method of panel data analysis is conducted. After both fixed affect estimation and random effect estimation is performed, fixed effect estimation results are confirmed according to the conclusion of Hausman test. Then, Woolridge autocorrelation test and BreuschPagan heteroscedasticity test are conducted. The estimations are performed with robust standard errors using White (1980) estimator. The empirical conclusions of this study which is countrylevel demonstrate that research and development investment, capital accumulation and foreign value added effect the domestic value added positively. Communication equipment investments effects domestic value added negatively and computing equipment investment and productivity are statistically insignificant. 
Optimum Journal of Economics and Management Sciences, Vo1. 7, No. 1- http://dergipark.gov.tr/optimum Alkın Kasaplar - The Determinants of Domestic Value Added in Exports of European Union Countries 